IZA DP No. 9943

Explaining the Male Native-Immigrant Employment Gap in Sweden:

The Role of Human Capital and Migrant Categories

Marc-André Luik

Henrik Emilsson

Pieter Bevelander

May 2016 


\title{
Explaining the Male Native-Immigrant Employment Gap in Sweden: The Role of Human Capital and Migrant Categories
}

\author{
Marc-André Luik \\ Helmut Schmidt University Hamburg \\ Henrik Emilsson \\ MIM, Malmö University \\ Pieter Bevelander \\ MIM, Malmö University and IZA \\ Discussion Paper No. 9943 \\ May 2016 \\ IZA \\ P.O. Box 7240 \\ 53072 Bonn \\ Germany \\ Phone: $+49-228-3894-0$ \\ Fax: +49-228-3894-180 \\ E-mail: iza@iza.org
}

Any opinions expressed here are those of the author(s) and not those of IZA. Research published in this series may include views on policy, but the institute itself takes no institutional policy positions. The IZA research network is committed to the IZA Guiding Principles of Research Integrity.

The Institute for the Study of Labor (IZA) in Bonn is a local and virtual international research center and a place of communication between science, politics and business. IZA is an independent nonprofit organization supported by Deutsche Post Foundation. The center is associated with the University of Bonn and offers a stimulating research environment through its international network, workshops and conferences, data service, project support, research visits and doctoral program. IZA engages in (i) original and internationally competitive research in all fields of labor economics, (ii) development of policy concepts, and (iii) dissemination of research results and concepts to the interested public.

IZA Discussion Papers often represent preliminary work and are circulated to encourage discussion. Citation of such a paper should account for its provisional character. A revised version may be available directly from the author. 


\section{ABSTRACT \\ Explaining the Male Native-Immigrant Employment Gap in Sweden: The Role of Human Capital and Migrant Categories}

Despite having one of the most celebrated labor market integration policies, the nativeimmigrant employment gap in Sweden is one of the largest among the OECD countries. In this study, we use unique Swedish register data to try to explain the employment gap between male immigrants and natives. The results show that the traditional human capital theory only explains a small share of the immigrant-native gap. After controlling for human capital, demographic and contextual factors, large unexplained employment gaps still persists between immigrants and natives and between migrant categories. Our analysis indicates that admission category is an important determinant of employment integration, and that humanitarian and family migrants suffer from low transferability of their country specific human capital. The article highlights the need to consider migrant categories in integration research, and take into account international human capital transferability when explaining employment outcomes for immigrants.

JEL Classification: F22, J61, J68

Keywords: labour market integration, Sweden, human capital, migration categories, employment gaps

Corresponding author:

Pieter Bevelander

MIM

Malmö University

20506 Malmö

Sweden

E-mail: pieter.bevelander@mah.se 


\section{Introduction}

According to the latest Migrant Integration Policy Index (MIPEX 2015), Sweden is ranked as having the most optimal labor market integration policies of the 38 countries covered in the index. At the same time, Sweden, as a relatively high immigration intake country, has for a long time had great difficulty accommodating these immigrants into the labor market (Bevelander 2011). According to the OECD, the native-immigrant employment gap is one of the largest among the OECD countries (OECD/European Union 2015).

This article explores possible explanations for this large and persistent employment gap. We focus on two main explanations: the role of both human capital and of the composition of the immigrants. According to human capital theory (Becker 1992), it is the differences in human capital that determine success in the labor market. However, immigration complicates this relationship due to the difficulties involved in transferring human capital (Chiswick and Miller 2009). Another explanation that has been highlighted in recent years is the impact of a migrant's admission status, and the categories according to which immigrants are granted access to a new country. The OECD (2014: 37) writes that the migration category is the single largest determinant of labor market integration outcomes. They note that humanitarian and family migrants struggle with labor market integration in all countries, and that the different categories into which immigrants are slotted on arrival account for most of the cross-country differences in labor market outcomes.

The relative importance of human capital characteristics and migrant categories for employment outcomes is an important issue, particularly in a country such as Sweden, which is characterized by large - primarily humanitarian and family - immigration flows. The challenge of labor market integration could possibly be accentuated by this composition of migrants coming to Sweden. There are two main possible additional challenges for these two migrant categories. Firstly, humanitarian and family migrants tend to have lower levels of human capital and that which they $d o$ have tends to be less internationally transferable. Secondly, and related to the first point, there can be a selection effect whereby unobservable factors also contribute to humanitarian and family migrants' lower labor market success, regardless of observable human capital.

The overall aim of this article is to study the extent to which human capital - operationalized as level and type of education - and migration categories can explain the labor market gap between natives and the foreign-born. This leads to two research questions:

- To what extent does the individual level of human capital explain differences in employment integration between natives and the various categories of immigrants?

- How important is the migrant category itself in explaining the employment gap between natives and immigrants?

\subsection{Migration and labour market integration: the Swedish context}

According to Eurostat (2014) Sweden, compared to other European Union (EU) countries, is characterized by high immigration with a majority share of humanitarian and family migrants. The country is one of the major destinations for asylum-seekers (Bitoulas 2015) and the absence of income requirements (Borevi 2014) has favored subsequent family migration. Labor migration from outside the EU was quite small-scale from the beginning of the 1970s up until the 2008 liberalization of Sweden's labour migration policy (Emilsson 2016), which the OECD (2011) deems to be one of the world's most open. Because of this, the number of foreign-born 
people has increased rapidly in Sweden over recent decades. Since 2000, the stock of migrants has increased by almost $60 \%$ to over 1.6 million, representing $16.5 \%$ of the population in 2014.

Figure 1 shows the employment gap between the stock of native-born workers and three geographical groups of foreign-born workers over time. Since the early 2000s, the gaps have been quite stable. Persons born in Nordic countries have an employment rate of about $65 \%$ and immigrants from EU/EFTA countries about $5 \%$ lower. Immigrants born outside EU/EFTA countries have an employment rate of approximately $50 \%$. In recent years it has increased slightly and was about $55 \%$ in 2013. This study has its main focus on the latter group: immigrants from outside the EU/EFTA.

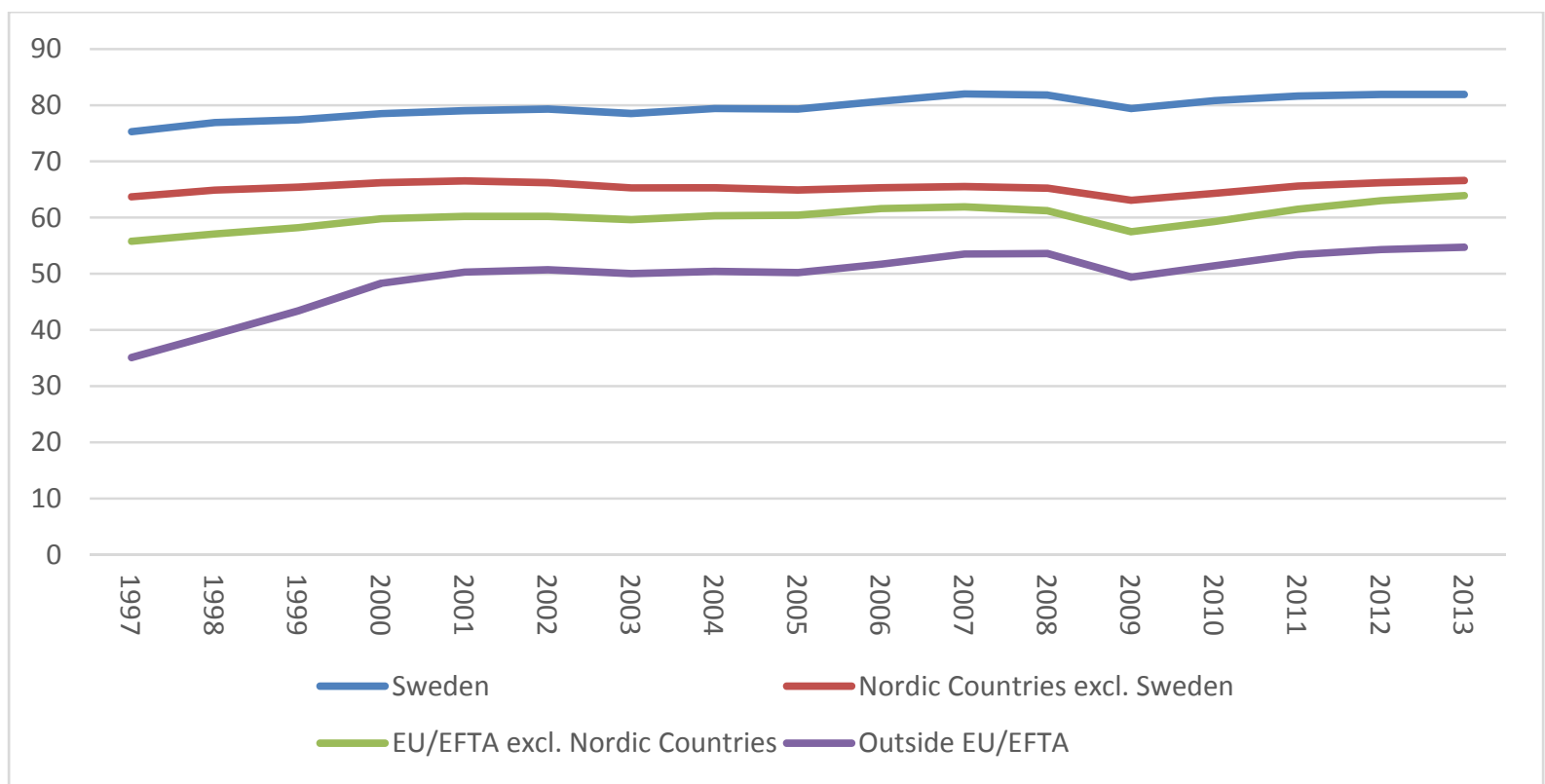

Fig. 1 Employment rate, 20-64 years, by region of birth

Source: Statistics Sweden

\subsection{Explaining labour market integration for different migrant groups}

In standard labor market supply studies it is assumed that the probability of working is determined by the level of human capital. This includes formal education, labor market experience and skills acquired at work. One of the challenges of human capital theory when it comes to migration is to take into account the migration-related depreciation of human capital. Skills may not be perfectly transferable across countries. Chiswick et al. (2005) define skills as labor market information, destination-language proficiency, and occupational licenses, certifications or credentials, as well as more narrowly defined task-specific skills. They exemplify the problem of transferability with three types of high-level occupation - economist, medical doctor and lawyer:

Country-specific skills for the economist may include language and style of practice. The medical doctor has less transferable skills because, in addition to language and style of practice, the practice of medicine requires a license specific to the destination. The skills of lawyers are even less transferable across countries because, in addition to the above, the legal system ... varies sharply across countries (2005: 335). 
According to their theory, those with the least transferable skills among potential migrants are not likely to become economic migrants. Refugees, on the other hand, base their migration decision, in part, on a different set of intentions. Income differentials could also be important factors for refugees, but their decisions are also influenced by non-economic factors concerning their safety and security. In essence, refugee streams include a larger proportion of immigrants who are less adapted for labor market integration (Chiswick et al. 2005).

In the same vein, Aydemir (2011) stresses that favorable selection in human capital characteristics do [sic] not always translate into better labor market outcomes. This is because many of these characteristics, such as schooling and experience, that are almost always acquired in source countries, and have little or no return in the host country labor market and, hence, have very limited power in predicting short-term labor market outcomes (2011: 453454).

He concludes that there are many unobservables that are important in determining the quality and relevance of the human capital which immigrants take to the host country and may result in skill transferability problems or a mismatch between demand and supply.

We understand this argument as being of significant importance for the Swedish case. The Swedish system of labor migration is employment-driven and all labor migrants must have an offer of employment in order to obtain a work permit. The employment offer itself should be a sign that the migrants' skills are useful and acknowledged by the employer. The majority of high-skilled labor migrants are employed as computer specialists in English-speaking work environments (Emilsson and Magnusson 2015), which implies that their human capital did not decrease due to insufficient knowledge of the host-country language. However, few humanitarian and family migrants have Swedish-language skills before entering the country, which no doubt increases the depreciation of their human capital. Thus, in contrast to labor migrants, humanitarian and family migrants could be disadvantaged due to both differences in their education levels and their transferability.

There may also be differences in employment opportunities between humanitarian and family migrants. Again, Aydemir (2011) argues that family migrants often have access to kinship networks in the host country which can facilitate access to crucial information regarding the labor market and may initiate investments in human capital prior to arrival that are valued in the host-country labour market. These types of network may also help to overcome barriers in the labor market through job contacts or a better knowledge of processes leading to the recognition of credentials. In Sweden, humanitarian and family migrants have access to different services. While all humanitarian migrants have the right to a two- to threeyear introduction program, only the family of recent humanitarian migrants have the same right. However, most services are also available to family migrants - for example, free language training.

\subsection{The importance of migrant category on employment outcomes}

There is growing evidence that both human capital and migration category are important factors explaining the labour market success of immigrants. The influence of formal education on immigrants' employment and earnings has proved positive, especially if some of this education is obtained in Sweden (Nordin 2007). However, differences in formal education do not completely explain the employment differential between native and foreign-born workers (Eriksson 2010). Szulkin et al. (2013) suggest that it is the composition of the immigrant group in Sweden which is probably the factor that can best explain the native-immigrant employment gap in Sweden compared to other countries. In other words, the gap between natives and the foreign-born is not explained by systematic differences in characteristics, like education, age, family status or country of origin. 
However, in the Swedish and Canadian contexts, Bevelander (2011) and Bevelander and Pendakur (2014) confirm that human capital characteristics do matter for the labor market integration of non-economic migrants. Controlling for personal, contextual and immigrant intake, Bevelander (2011) finds that family-reunion migrants integrate into the employment market much faster than asylum claimants who, in turn, integrate more quickly than resettled refugees. Thus, the results confirm the importance of admission categories.

Studies from other countries confirm the importance of the admission category for labor market integration, especially in traditional settler countries such as Australia, Canada, New Zealand and the US. The studies show that the points system for labour migrant selection generates a more-highly skilled immigrant flow than those admitted for family reasons (Aydemir 2011; Cobb-Clark 2000; Jasso and Rosenzweig 1995). Several studies from Australia show that refugees have greater difficulty in finding employment than other immigrants (Chiswick and Miller 1992; Wooden 1990). De Silva (1997) and DeVoretz et al. (2004) examine the labor market integration of skilled immigrants in Canada compared both to assisted relatives and to refugees and find that the latter groups have a lower employment success rate. In all studies, the gap gets smaller over time. Connor (2010) studies the US employment gap between refugees and natives and shows a refugee disparity in earnings and occupational attainment. However, employment rates are about the same for refugees as for other migrant categories. In Germany and Denmark, where the context is closer to that in Sweden, refugees and those who arrive through family reunification have a weaker position in the labour market compared to labour migrants (Constant and Zimmermann 2005).

\section{Data and methodology}

\subsection{Data and descriptive statistics}

Our data originate from the STATIV database supplied by Statistics Sweden and are extracted from the population register for the year 2011. The advantages of this dataset are that it includes all residents in Sweden and collects data from several different - i.e. demographic, education, employment and immigration - registers. Moreover, our dataset is updated with the actual admission status of immigrants when granted legal status in Sweden and allows us to differentiate between immigration categories.

Our analysis focuses on the male population aged between 25 and 59. The employment gap between the natives and the foreign-born is greater for women (Bevelander 2005; Bevelander and Groeneveld 2006), and by only looking at the male population can we reduce the eventual effects of cultural factors (Antecol 2001). While including all natives, we limit immigrants to non-EU/EES immigrants with an entry year between 1990 and 2009. We exclude immigrants with less than two years' residence, since a large majority of new immigrants are following introduction programs or other forms of education such as language training and adult education during this first period in Sweden (Statistics Sweden 2012). This procedure ensures that the sample represents the differences between labor migrants and other migration categories, since all labor migrants have a job upon arrival. The age is chosen to exclude young individuals still in education and older people who have taken early retirement. Lastly, we exclude immigrants from EU/EES countries who have an automatic right to immigrate if they find employment or are self-sufficient.

Our key dependent variable is employment status. We use the standard EU definition of employment also used by Statistics Sweden. Our human capital measure, educational level, is based upon the Swedish system of education and is comprised of seven levels (see Table 1). From the same source originates our information on a distinct feature of our study - the field 
of education. This measure captures nine different fields and an "unknown" category (again, see Table 1). By definition the lower education levels are classified as 'general education'. Being the key advantage of the STATIV dataset used in this analysis, the classification includes immigrant arrival categories, i.e. admission status for all immigrants. We distinguish immigrants into three categories: labor migrants, family reunion migrants and refugees. Further information on the individual is summarized by the variables age, marital status, number of children and whether the individual lives in a county with larger urban agglomeration such as Stockholm, Gothenburg or Malmö, or elsewhere Sweden, as well as their area of origin (9) including Sweden. Finally we have variables for the average age at arrival and years since immigration.

We omit individuals with missing information on dependent or independent variables. Ultimately our sample consists of 1,699,060 natives and 117,049 immigrants. Table 1 displays the sample characteristics of male Swedish natives (2) and immigrants (3). The latter we break down according to our information on immigrant intake category (4-6). At the same time the reported sample characteristics also summarize our set of dependent and independent variables. Column 2 shows that the large majority (72\%) of our immigrants entered Sweden via the humanitarian intake category. Another $25 \%$ entered the country in the family intake category. Hence, only $3 \%$ arrived as labor immigrants. Consequently, the distribution of immigrants in Sweden is far from even. Almost $90 \%$ of all Swedish males in our sample are employed. Among the group of immigrants, the highest employment rate is found for the labor intake category (83\%). However, only slightly more than $60 \%$ of family and humanitarian immigrants are employed. Hence, not accounting for intake category could mask a great deal of immigrant employment heterogeneity.

Classic human-capital theory would expect groups with lesser human capital to have a lower employment rate. Hence, the differences between categories could be driven by differences in human capital rather than just their membership and correlated unobservables. Half of all natives have some secondary education, whereas $34 \%$ have continued to higher education. A sizable $83 \%$ of all labor immigrants have pursued their education beyond upper-secondary level. This makes them, on average, more skilled than their native counterparts. Roughly the same relative share of natives, humanitarian and family immigrants have received a higher education. However, in contrast to natives, a larger share of them has lower, as opposed to medium, educational attainment.

The stream of education followed by natives is mostly technical (42\%), general (19\%) or has a social science background (14\%). In general, while this hierarchy holds for family and humanitarian immigrants, its overall share is smaller in these groups. General education is far more prevalent for the latter categories. This can be explained by the mechanical link between low and general levels of education. In line with this argument, the large share of high-skilled individuals among labor immigrants comes with the largest share of specialization, especially in the natural sciences.

According to socio-economic factors, the immigrants in our sample are younger, are more likely to cohabit and have more children than their native counterparts. ${ }^{1}$ While roughly half of all Swedish natives are single, the same holds true for only about a quarter of humanitarian and family immigrants. In contrast to the remaining intake groups, labor immigrants are the most likely to be single and have substantially fewer children. A distinct feature of humanitarian immigrants is that they are comparably less clustered in the three big urban counties of Sweden.

\footnotetext{
${ }^{1}$ In cross-sections, each age is equal to a different birth cohort. In addition, age today is a sum of age at immigration and years since immigration. Rather than assuming similar qualities in the different cohorts, when talking about age we mean the joint effect of cohort and age.
} 
Table $1 \quad$ Mean characteristics

\begin{tabular}{|c|c|c|c|c|c|}
\hline & Native & Immigrant & $\begin{array}{c}\text { Immigrant } \\
\text { (labor) }\end{array}$ & $\begin{array}{l}\text { Immigrant } \\
\text { (family) }\end{array}$ & $\begin{array}{c}\text { Immigrant } \\
\text { (humanitarian) }\end{array}$ \\
\hline \multicolumn{6}{|l|}{ Employment } \\
\hline Employed & 0.88 & 0.63 & 0.81 & 0.64 & 0.62 \\
\hline \multicolumn{6}{|l|}{ Education } \\
\hline Pre-secondary <9 & 0.01 & 0.14 & 0.04 & 0.12 & 0.16 \\
\hline Pre-secondary 9 & 0.12 & 0.11 & 0.03 & 0.13 & 0.10 \\
\hline Secondary $<3$ & 0.29 & 0.21 & 0.06 & 0.21 & 0.21 \\
\hline Secondary 3 & 0.23 & 0.18 & 0.04 & 0.17 & 0.19 \\
\hline Post-secondary $<3$ & 0.15 & 0.15 & 0.19 & 0.16 & 0.15 \\
\hline Post-secondary $>=3$ & 0.19 & 0.20 & 0.48 & 0.20 & 0.18 \\
\hline Scientific & 0.01 & 0.01 & 0.16 & 0.02 & 0.01 \\
\hline \multicolumn{6}{|l|}{ Education type } \\
\hline General & 0.19 & 0.36 & 0.10 & 0.36 & 0.37 \\
\hline Pedagogics & 0.03 & 0.03 & 0.02 & 0.02 & 0.03 \\
\hline Humanities & 0.04 & 0.04 & 0.04 & 0.05 & 0.03 \\
\hline Social sciences & 0.14 & 0.10 & 0.11 & 0.11 & 0.10 \\
\hline Natural sciences & 0.03 & 0.05 & 0.20 & 0.06 & 0.04 \\
\hline Technical & 0.42 & 0.24 & 0.37 & 0.21 & 0.24 \\
\hline Agriculture & 0.03 & 0.01 & 0.01 & 0.01 & 0.01 \\
\hline Health & 0.04 & 0.05 & 0.06 & 0.05 & 0.05 \\
\hline Services & 0.06 & 0.04 & 0.02 & 0.04 & 0.04 \\
\hline Unknown & 0.02 & 0.08 & 0.07 & 0.08 & 0.08 \\
\hline \multicolumn{6}{|l|}{ Demographics } \\
\hline Age & 42.26 & 40.16 & 35.54 & 38.67 & 40.85 \\
\hline Couple & 0.39 & 0.61 & 0.51 & 0.55 & 0.63 \\
\hline Single & 0.51 & 0.24 & 0.43 & 0.27 & 0.23 \\
\hline Divorced & 0.09 & 0.14 & 0.06 & 0.18 & 0.13 \\
\hline Widowed & 0.00 & 0.00 & 0.00 & 0.00 & 0.00 \\
\hline Children & 0.96 & 1.33 & 0.50 & 1.20 & 1.40 \\
\hline \multicolumn{6}{|l|}{ County } \\
\hline Stockholm & 0.21 & 0.29 & 0.48 & 0.39 & 0.25 \\
\hline Gothenburg & 0.17 & 0.18 & 0.16 & 0.17 & 0.19 \\
\hline Skane & 0.12 & 0.16 & 0.10 & 0.15 & 0.17 \\
\hline \multicolumn{6}{|l|}{ Immigration } \\
\hline Years since immigration & & 11.94 & 5.71 & 12.00 & 12.15 \\
\hline Age at immigration & & 28.22 & 29.83 & 26.66 & 28.70 \\
\hline Rest of Europe & & 0.32 & 0.16 & 0.24 & 0.35 \\
\hline Africa & & 0.14 & 0.09 & 0.21 & 0.12 \\
\hline North America & & 0.02 & 0.06 & 0.07 & 0.01 \\
\hline South America & & 0.03 & 0.03 & 0.07 & 0.02 \\
\hline Asia & & 0.09 & 0.48 & 0.12 & 0.07 \\
\hline Oceania & & 0.01 & 0.02 & 0.02 & 0.00 \\
\hline Soviet Union & & 0.00 & 0.01 & 0.00 & 0.00 \\
\hline Middle East & & 0.38 & 0.14 & 0.27 & 0.43 \\
\hline Labor & & 0.03 & & & \\
\hline Family & & 0.25 & & & \\
\hline Humanitarian & & 0.72 & & & \\
\hline Observations & 999,060 & 117,049 & 3,247 & 29,193 & 84,609 \\
\hline
\end{tabular}

Note: All variables except the number of children, age, years since immigration and age at immigration are mean dummy variables and can be interpreted as percentages. The remaining variables are traditional level means.

Finally, we compare immigrant-specific sample characteristics. On average, our group of immigrants entered the country about 12 years ago at the age of 28. However, compared to humanitarian and family immigrants, labor immigrants arrived more recently and, hence, 
acquired only half of the other immigrants' experience in Sweden. Moreover, they arrived at a slightly older age than their intake-category counterparts. Here, it is worth noting that labor immigrants per se do not arrive in childhood or adolescence. More than two-thirds of our immigrant sample are from the Middle East (38 \%) and the Rest of Europe (32\%), excluding Northern European countries and the EU 27. The bulk of the remaining immigrants originated in Africa or Asia (23\%). In contrast to humanitarian immigrants, individuals in the family intake category are more often from Africa, Asia and the Americas (47\%). Hence, family immigrants show the widest source-country dispersion. Asian origin, excluding the Middle East, is particularly common for labor immigrants.

Our descriptive analysis documents immigrant-native differences according to employment, human capital and other socio-economic factors. Moreover, these characteristics are far from uniform across the different intake categories. In fact, ignoring intake category information masks the underlying employment heterogeneity. While, as expected, the related human capital is lower for the less-integrated immigrant groups, labor immigrants also differ markedly according to socio-economic variables like marital status. Moreover, all intake categories seem to have a distinct set of immigrant-specific characteristics, like source region or years since immigration.

\subsection{Methodology: determinants of employment and employment gap decomposition}

Our descriptive analysis indicates different employment gaps for the various intake categories. As expected, these groups differ in terms of human capital. However, considerable heterogeneity in socio-economics and immigrant-specific characteristics make our interest groups hard to compare and bias the assessment of human capital and category importance for employment.

As a consequence, we turn to a multivariate non-linear probit framework. The employment status of individual $i, E_{i, g}$ is a function of the human capital matrix, $E d u c_{i, g}$ including vectors for education level and type. Moroever employment is related to socio-economic and regional controls, $\operatorname{Dem}_{i, g}$ and $\operatorname{Reg}_{i, g}$. Coefficients, $\beta_{g}$, capture the corresponding estimated coefficients and, hence, the estimated relationship with employment status. $\varepsilon_{i, g}$ is the individual group-specific heteroscedasticity-consistent error term. The non-linear relationship is modelled via the cumulative standard normal distribution $\Phi$. We run five regressions, one for each group g: natives, immigrants and their intake categories.

$$
\operatorname{Pr}\left(E_{i, g}=1 \mid X=x\right)=\Phi\left(\beta_{0, g}+\beta_{D e m, g} \operatorname{Dem}_{i, g}+\beta_{\text {Reg,g }} \operatorname{Reg}_{i, g}+\beta_{E d u c, g} E d u c_{i, g}+\varepsilon_{i, g}\right)
$$

For each group, estimated coefficient matrix $\beta_{E d u c, g}$ captures the ceteris paribus association between human capital and employment status. Running separate regressions allows us to compare employment returns per population group.

As a next step, we pool natives with immigrants, extend our independent variables by an immigrant indicator and estimate the respective coefficient. This estimate can be interpreted as the category-specific immigrant-native gap. In particular, we obtain the raw gap by only including the immigrant indicator and learn about gap drivers via sequentially adding independent variables. For instance, if the estimated gap decreases after the inclusion of human capital indicators, part of the gap is explained by differences in human capital. In order to get more-qualified evidence in favor of intake categories, we replace the immigrant indicator by more-informative intake category indicators. If the pattern of our descriptive results is robust to the inclusion of controls, the effect of categories is not just the result of observable group differences. 
However, while a pooled regression accounts for group differences, it also assumes that group returns are uniform. Consequently, it does not account for the possibility that immigrants experience, for example, a different return on education than Swedish natives. In order to account for this possibility, we conduct a generalized non-linear two-way Blinder-Oaxaca decomposition analysis, as suggested by Yun (2004). Crucial to our analysis, it allows us to calculate the gap contribution of human capital differences in characteristics and returns.

Our average group employment difference between $\overline{E_{\text {lmg }}}$ and $\overline{E_{\text {nat }}}$ can be decomposed into endowment effects $\Delta X$ and coefficient effect $\Delta \beta$. Endowment effects are based on observable differences in characteristics. Hence, they are called the 'explained gap', whereas coefficient effects are also called the 'unexplained gap'. The decomposition makes use of the characteristics $X_{i m g}$ and $X_{\text {nat }}$ and estimated coefficients $\beta_{i m g}$ and $\beta_{\text {nat }}$ from our groupspecific regressions.

$$
\begin{gathered}
\overline{E_{\text {nat }}}-\overline{E_{\text {lmg }}}=\Delta X+\Delta \beta \\
\Delta X=\left[\Phi\left(X_{\text {nat }} \beta_{\text {nat }}\right)-\Phi\left(X_{\text {img }} \beta_{\text {nat }}\right)\right] \\
\Delta \beta=\left[\Phi\left(X_{\text {img }} \beta_{\text {nat }}\right)-\Phi\left(X_{\text {img }} \beta_{\text {img }}\right)\right]
\end{gathered}
$$

As mentioned earlier, we are able to calculate the contribution of any variable for each gap. ${ }^{2}$ Finally, we follow Jann (2008) and include a group dummy in our pooled regression to obtain non-discriminatory coefficients and avoid over- or undervaluation of one of the two groups. As the choice of omitted categories affects the detailed decomposition results (Oaxaca and Ransom 1999), we follow the suggestion of Yun (2005) and run a regression for each possible benchmark category and average the resulting estimated coefficients. This framework can be reached via normalizing. The estimated contributions to the unexplained gap can be interpreted as deviation from the grand mean.

\section{Results: multivariate regression}

Table 2 displays the estimated average marginal effects of human capital on the employment likelihood for each population group. Controlling for socio-economic and regional differences, human capital significantly influences the employment likelihood. Higher educational attainment has a positive and significant effect for natives and overall immigrants. Having a three-year secondary-school qualification instead of less than nine years of education increases the likelihood of being employed by 17 percentage points for natives and 22 percentage points for all immigrants. For humanitarian immigrants and, to a much smaller extent, for family reunion migrants, employment returns on increasing educational attainment up to secondary level are greater. However, the return on increasing educational attainment to a post-secondary level is greater for natives, especially compared to family immigrants. Labor immigrants show insignificant returns on increasing educational attainment. There are two reasons for this finding: roughly $73 \%$ of labor immigrants have a qualification higher than secondary level, so that there are only few individuals in the lower categories. Second, when conducting a bivariate analysis between employment rates and educational attainment, the educational gradient is somewhat flat (see Table 7 in the Appendix). For instance, for labor immigrants, fewer than nine years of education and research education both show an employment rate of $80 \%$. In contrast, humanitarian and family immigrants show a substantially more-pronounced education gradient.

${ }^{2}$ The contribution is based on weighing each gap. Therefore all contributions sum to 1. For details on the calculation of weights, see Yun (2004). 
Changing education fields from general to technical or agricultural increases the likelihood of being employed by 5 and 6 percentage points, respectively. For humanitarian and family immigrants, having a health or technical education increases the likelihood by up to 17 percentage points. In general all specializations except the humanities result in a positive effect on employment. This makes intuitive sense, as specialization is by definition strongly correlated with higher educational attainment. For labor immigrants, the only educational field that comes close to guaranteeing a significant increase in employment likelihood is technical education. Again, the same argument of a flat education-field gradient applies. It is worth stressing that these flat gradients should not be interpreted as the non-transferability of human capital.

Table 2 Probabilty model of employment

\begin{tabular}{|c|c|c|c|c|c|}
\hline & Native & Immigrant & $\begin{array}{c}\text { Immigrant } \\
\text { (labor) }\end{array}$ & $\begin{array}{c}\text { Immigrant } \\
\text { (family) }\end{array}$ & $\begin{array}{c}\text { Immigrant } \\
\text { (humanitarian) }\end{array}$ \\
\hline \multicolumn{6}{|l|}{ Education } \\
\hline Pre-secondary 9 & $\begin{array}{l}0.09^{* * *} \\
(0.00)\end{array}$ & $\begin{array}{l}0.09^{* * *} \\
(0.01)\end{array}$ & $\begin{array}{l}-0.07 \\
(0.05)\end{array}$ & $\begin{array}{l}0.08^{* * *} \\
(0.01)\end{array}$ & $\begin{array}{l}0.09^{* * *} \\
(0.01)\end{array}$ \\
\hline Secondary $<3$ & $\begin{array}{l}0.11^{* * *} \\
(0.00)\end{array}$ & $\begin{array}{l}0.15^{* * *} \\
(0.01)\end{array}$ & $\begin{array}{l}-0.06 \\
(0.05)\end{array}$ & $\begin{array}{c}0.12^{* * *} \\
(0.01)\end{array}$ & $\begin{array}{l}0.16^{* * *} \\
(0.01)\end{array}$ \\
\hline Secondary 3 & $\begin{array}{l}0.17^{* * *} \\
(0.00)\end{array}$ & $\begin{array}{l}0.22^{* * *} \\
(0.01)\end{array}$ & $\begin{array}{l}-0.06 \\
(0.05)\end{array}$ & $\begin{array}{l}0.18^{* * *} \\
(0.01)\end{array}$ & $\begin{array}{l}0.23^{* * *} \\
(0.01)\end{array}$ \\
\hline Post-secondary $<3$ & $\begin{array}{l}0.15^{* * *} \\
(0.00)\end{array}$ & $\begin{array}{l}0.11^{* * *} \\
(0.01)\end{array}$ & $\begin{array}{c}0.01 \\
(0.05)\end{array}$ & $\begin{array}{l}0.09^{* * *} \\
(0.02)\end{array}$ & $\begin{array}{l}0.11^{* * *} \\
(0.01)\end{array}$ \\
\hline Post-secondary $>=3$ & $\begin{array}{l}0.18^{* * *} \\
(0.00)\end{array}$ & $\begin{array}{l}0.17^{* * *} \\
(0.01)\end{array}$ & $\begin{array}{l}-0.02 \\
(0.05)\end{array}$ & $\begin{array}{l}0.15^{* * *} \\
(0.01)\end{array}$ & $\begin{array}{l}0.17^{* * *} \\
(0.01)\end{array}$ \\
\hline Scientific & $\begin{array}{l}0.19^{* * *} \\
(0.00)\end{array}$ & $\begin{array}{l}0.21^{* * *} \\
(0.01)\end{array}$ & $\begin{array}{l}-0.04 \\
(0.06)\end{array}$ & $\begin{array}{l}0.17^{* * *} \\
(0.02)\end{array}$ & $\begin{array}{l}0.18^{* * *} \\
(0.02)\end{array}$ \\
\hline \multicolumn{6}{|l|}{ Type } \\
\hline Pedagogics & $\begin{array}{l}0.04^{* * *} \\
(0.00)\end{array}$ & $\begin{array}{l}0.06^{* * *} \\
(0.01)\end{array}$ & $\begin{array}{c}0.00 \\
(0.08)\end{array}$ & $\begin{array}{l}0.06^{* *} \\
(0.02)\end{array}$ & $\begin{array}{c}0.07^{* * *} \\
(0.01)\end{array}$ \\
\hline Humanities & $\begin{array}{c}-0.04^{* * *} \\
(0.00)\end{array}$ & $\begin{array}{l}-0.03^{* *} \\
(0.01)\end{array}$ & $\begin{array}{c}0.03 \\
(0.06)\end{array}$ & $\begin{array}{l}-0.00 \\
(0.02)\end{array}$ & $\begin{array}{c}-0.04^{* * *} \\
(0.01)\end{array}$ \\
\hline Social sciences & $\begin{array}{l}0.01^{* * *} \\
(0.00)\end{array}$ & $\begin{array}{l}0.04^{* * *} \\
(0.01)\end{array}$ & $\begin{array}{l}-0.03 \\
(0.05)\end{array}$ & $\begin{array}{l}0.03^{*} \\
(0.01)\end{array}$ & $\begin{array}{l}0.05^{* * *} \\
(0.01)\end{array}$ \\
\hline Natural sciences & $\begin{array}{l}-0.00 \\
(0.00)\end{array}$ & $\begin{array}{l}0.05^{* * *} \\
(0.01)\end{array}$ & $\begin{array}{c}0.03 \\
(0.05)\end{array}$ & $\begin{array}{l}0.05^{* * *} \\
(0.02)\end{array}$ & $\begin{array}{l}0.04^{* * *} \\
(0.01)\end{array}$ \\
\hline Technical & $\begin{array}{l}0.05^{* * *} \\
(0.00)\end{array}$ & $\begin{array}{l}0.10^{* * *} \\
(0.01)\end{array}$ & $\begin{array}{c}0.09 \\
(0.05)\end{array}$ & $\begin{array}{l}0.09^{* * *} \\
(0.01)\end{array}$ & $\begin{array}{l}0.10^{* * *} \\
(0.01)\end{array}$ \\
\hline Agriculture & $\begin{array}{l}0.06^{* * *} \\
(0.00)\end{array}$ & $\begin{array}{l}0.06^{* * *} \\
(0.01)\end{array}$ & $\begin{array}{c}0.05 \\
(0.08)\end{array}$ & $\begin{array}{l}0.07^{* *} \\
(0.03)\end{array}$ & $\begin{array}{l}0.07^{* * *} \\
(0.02)\end{array}$ \\
\hline Health & $\begin{array}{l}0.02^{* * *} \\
(0.00)\end{array}$ & $\begin{array}{l}0.14^{* * *} \\
(0.01)\end{array}$ & $\begin{array}{l}-0.04 \\
(0.06)\end{array}$ & $\begin{array}{l}0.09^{* * *} \\
(0.02)\end{array}$ & $\begin{array}{l}0.17^{* * *} \\
(0.01)\end{array}$ \\
\hline Services & $\begin{array}{l}0.04^{* * *} \\
(0.00)\end{array}$ & $\begin{array}{l}0.07^{* * *} \\
(0.01)\end{array}$ & $\begin{array}{l}-0.05 \\
(0.07)\end{array}$ & $\begin{array}{l}0.06^{* * *} \\
(0.02)\end{array}$ & $\begin{array}{l}0.07^{* * *} \\
(0.01)\end{array}$ \\
\hline Unknown & $\begin{array}{l}0.01^{* * *} \\
(0.00)\end{array}$ & $\begin{array}{l}0.04^{* * *} \\
(0.01)\end{array}$ & $\begin{array}{l}-0.06 \\
(0.05)\end{array}$ & $\begin{array}{c}0.01 \\
(0.01)\end{array}$ & $\begin{array}{l}0.05^{* * *} \\
(0.01)\end{array}$ \\
\hline Controls & Yes & Yes & Yes & Yes & Yes \\
\hline$N$ & $1,699,060$ & 117,049 & 3,247 & 29,193 & 84,609 \\
\hline Pseudo $R^{2}$ & 0.094 & 0.050 & 0.068 & 0.047 & 0.054 \\
\hline Log-Lik. & $-557,372.61$ & $-73,414.58$ & $-1,480.64$ & $-18,192.87$ & $-53,324.91$ \\
\hline Chi2 & $93,367.48$ & $7,504.29$ & 200.60 & $1,694.84$ & $5,830.17$ \\
\hline
\end{tabular}


Our estimated controls for the above analysis are listed in Appendix Table 6. Again, there are differences in returns across our estimations. Among others, being in the oldest age group between 50 and 59 years old - has a strong negative effect on all immigrant groups, while for natives it increases their likelihood of being employed. The effects of being single, the number of children and living in any county other than Stockholm have uniform signs but different amplitudes for native and immigrant populations. For instance, being single has a larger association with natives, whereas living outside the county of Stockholm lowers the employment likelihood of humanitarian and family immigrants in particular.

\subsection{Result: pooled multivariate regression}

Column 1 of Table 3 shows our raw 'uncontrolled' immigrant-native employment gap from the pooled sample. In column 2 we replace this indicator by a more informative intake category indicator. After that we sequentially extend our immigrant indicator by a set of controls and, more prominently, human capital characteristics. In line with our descriptive results, the breakdown into intake categories indicates that an aggregate group substantially underestimates employment heterogeneity. Each category is a significant predictor of labor market participation. For all gaps, especially for family and humanitarian immigrants, controlling for socio-demographic and regional differences increases the employment gap. Consequently, these immigrant characteristics actually decrease the gap. However they increase the model fit. Adding educational attainment and type in columns 4 and 5 decreases the differential for all but labor immigrant-native, where the gap increases slightly. All regressions have in common that, after accounting for educational attainment, educational type contributes very little to the gap. For labor immigrants, none of the considered factors seem to contribute to the resulting gap. Here different unobserved factors seem to be at play. Finally, after the inclusion of all controls and human capital covariates, differences by intake categories remain substantial.

Table 3 Probabilty model of employment - pooled

\begin{tabular}{|c|c|c|c|c|c|}
\hline \multicolumn{6}{|c|}{ All } \\
\hline All immigrants & $\begin{array}{c}-0.26^{* * *} \\
(0.00)\end{array}$ & & & & \\
\hline Labor immigrants & & $\begin{array}{c}-0.07^{* * *} \\
(0.01)\end{array}$ & $\begin{array}{c}-0.09^{* * *} \\
(0.01)\end{array}$ & $\begin{array}{c}-0.10^{* * *} \\
(0.01)\end{array}$ & $\begin{array}{c}-0.10^{* * *} \\
(0.01)\end{array}$ \\
\hline Family immigrants & & $\begin{array}{c}-0.24^{* * *} \\
(0.00)\end{array}$ & $\begin{array}{c}-0.29^{* * *} \\
(0.00)\end{array}$ & $\begin{array}{c}-0.26^{* * *} \\
(0.00)\end{array}$ & $\begin{array}{c}-0.24^{* * *} \\
(0.00)\end{array}$ \\
\hline Humanitarian immigrants & & $\begin{array}{c}-0.27^{* * *} \\
(0.00)\end{array}$ & $\begin{array}{c}-0.34^{* * *} \\
(0.00)\end{array}$ & $\begin{array}{c}-0.30^{* * *} \\
(0.00)\end{array}$ & $\begin{array}{c}-0.29^{* * *} \\
(0.00)\end{array}$ \\
\hline$N$ & $1,816,109$ & $1,816,109$ & $1,816,109$ & $1,816,109$ & $1,816,109$ \\
\hline Pseudo $R^{2}$ & 0.032 & 0.033 & 0.086 & 0.106 & 0.112 \\
\hline Log-Lik. & $-692,343.36$ & $-692,061.20$ & $-653,954.18$ & $-639,206.09$ & $-634,990.51$ \\
\hline Chi2 & $47,989.48$ & $48,539.85$ & $112,926.44$ & $132,655.49$ & $139,294.19$ \\
\hline \multicolumn{6}{|c|}{ Controls } \\
\hline Category & No & Yes & Yes & Yes & Yes \\
\hline Demographic & No & No & Yes & Yes & Yes \\
\hline Education & No & No & No & Yes & Yes \\
\hline Educucation type & No & No & No & No & Yes \\
\hline
\end{tabular}

Notes: Robust standard errors in parentheses; ${ }^{*} p<0.05,{ }^{* *} p<0.01,{ }^{* * *} p<0.001$ 


\subsection{Results: non-linear decomposition analysis}

The predictive power of intake categories are based on the assumption that returns on characteristics are identical for all groups (Abdulloev et al. 2014). However, this assumption seems to be at odds with origin-specific returns on human capital (Friedberg 2000). In order to allow group-specific returns on characteristics, we run a decomposition analysis for each immigrant-native employment gap. Following decomposition logic, a large unexplained employment gap between any immigrant group and the native group indicates that the underlying gap is not driven by differences in observed characteristics but by either different returns or sheer group membership size (be it of immigrants or natives).

Table 4 lists the results of our gap decompositions. Each column refers to a different employment gap. The first panel includes information on the employment gap and its decomposition into explained and unexplained components. Here, we recall that the explained part captures differences in observed characteristics, while the unexplained part is the difference due to unequal returns on characteristics and intercepts. The second and third panel break down each component into individual contributions of educational attainment, educational type and the remaining control variables.

Table 4 Non-linear decomposition analysis

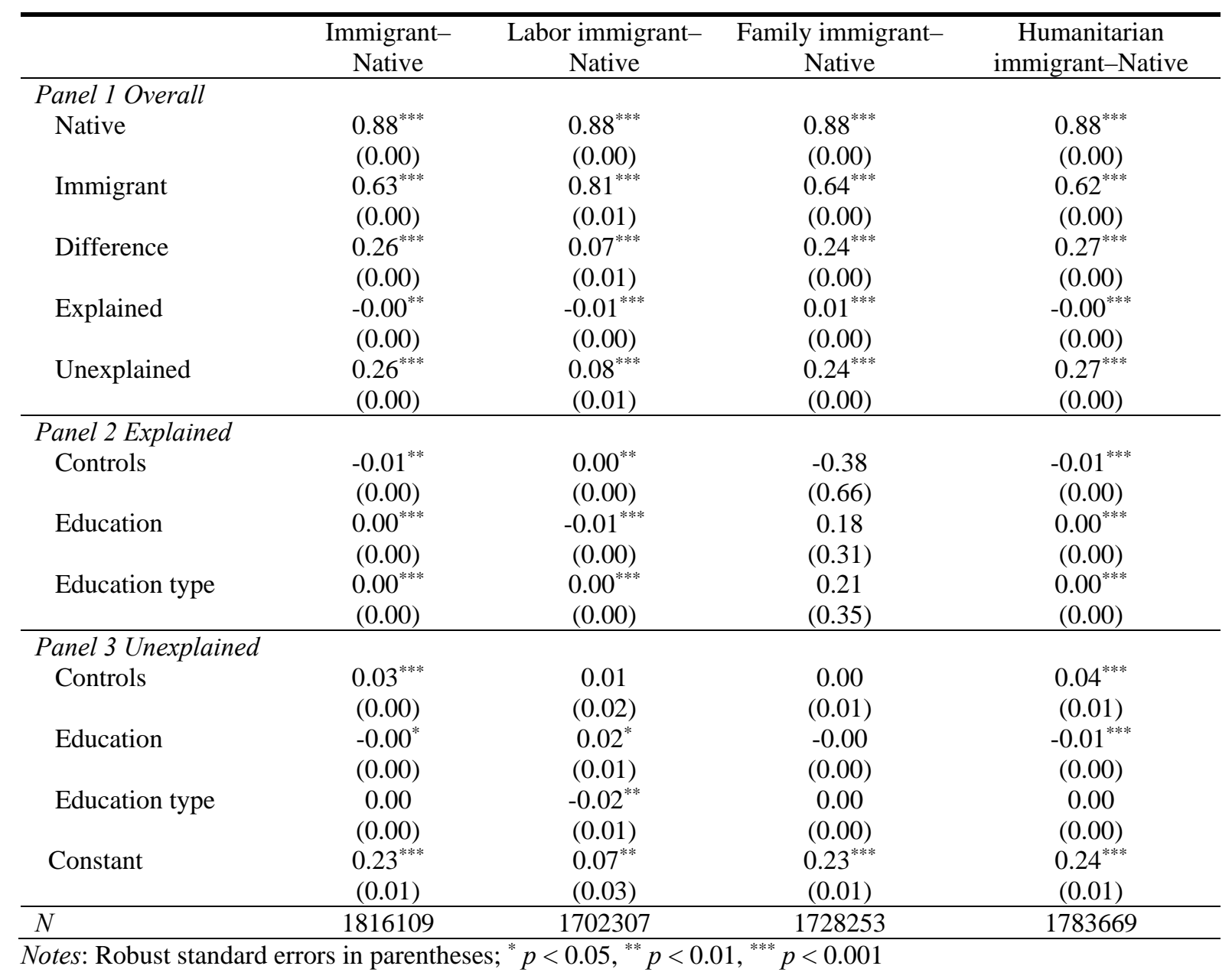


First, the predicted employment gaps closely resemble our pooled regression estimates and, hence, underline the need to account for intake information. For each gap, a substantial share cannot be explained by differences in observable group characteristics, including human capital and socio-demographics. Instead, differential returns to characteristics (coefficients) and sheer group membership (intercept) seem to be the main gap contributors. Only for family immigrants do comparatively less-favorable group characteristics seem to explain a significant share of the employment gap (column 3). However, their contribution to the overall employment difference only amounts to $4 \%(0.01 / 0.24)$. In fact, the characteristics of humanitarian and labor immigrants tend to narrow the employment gap with natives.

In order to understand which specific mean differences drive the explained gap, we turn to the detailed decomposition in Panel 2 of Table 4. Group differences in educational attainment and type increase the employment gap for family and humanitarian immigrants. Put differently, assimilation with the native distribution of educational attainment would decrease the underlying employment gaps. A closer look at the contribution of each level of educational attainment or type indicates a crucial role for the lower share of three-year secondary and technical education among immigrants (see Appendix Table 10). Instead, this seems to be offset by a higher share of pre-secondary educational attainment ( $<9$ years) and unknown education type (Appendix Table 10). As labor immigrants have by far the largest share of educational attainment, with at least post-secondary education $(>=3)$, differences with native educational characteristics do not drive but shrink the employment gap (-0.01). However, the economic magnitude for educational attainment and type is small and counteracted by regional and socio-demographic characteristics subsumed in the 'control' group. The larger share of married individuals and Stockholm-county residents, together with the greater number of children of family and humanitarian immigrants compared to natives, shrink the employment gap and offset human capital differences (Table 10). Also for labor immigrants the impact of socio-demographics reverses the trend. In particular, their younger average age and fewer children drives our gap of interest and offsets part of their more favorable human capital characteristics (Table 10). Altogether, by definition, these factors add up to the earliermentioned small net contribution of the differences in characteristics (explained gap).

Panel 3 displays the detailed decomposition of the unexplained gap and indicates which specific return differences drive or do not drive it. We find higher returns to educational attainment for humanitarian and family immigrants to shrink the employment gap (e.g. -0.01). Again, for labor immigrants the contribution is reversed. In fact, $25 \%(0.02 / 0.08)$ of their unexplained employment gap can be attributed to lower returns to educational attainment. Here, it is noteworthy that this does not necessarily imply a limited transferability of human capital. As argued earlier, the results are probably driven by the relatively flat educationemployment gradient. However, while the latter is offset by the similar gap-shrinking effect of education type, this pattern is not found for the remaining intake categories. Finally, particularly for the gap between natives and humanitarian immigrants, lower returns on sociodemographics seem to explain a fairly large share (0.04 of 0.27). Again the driving forces seem to be lower returns for being married and number of children (Appendix, Table 10). Overall, it is striking that the intercept, i.e. group membership, is the single largest gap contributor to the unexplained gap. It ranges from $87.5 \%(0.07 / 0.08)$ to $96 \%(0.23 / 0.24)$. This means that differences neither in characteristics nor in returns are the main gap drivers. Our results therefore underline the need to account for intake categories.

\subsection{Robustness checks}

Results from pooled regression and decomposition analysis suggest that the employment integration of immigrants varies depending on the underlying intake category. However, while 
we stress the need to account for immigrant heterogeneity according to intake category, our results could be driven by alternative omitted sources of heterogeneity. In the context of integration, one natural candidate is the source region of each individual. We rerun the decomposition analysis for the regions 'Rest of Europe', consisting of non-EU and nonNorthern European countries, 'Africa', Asia without the Middle East (from now on 'Asia'), the 'Middle East' and, for completeness, the smallest groups of immigrants from the 'Rest of the World', including the Americas, Oceania and the former Soviet Union. The results are listed in the Appendix (Tables 11-14).

Overall, our benchmark results seem to be robust to source regions. While the employment gap level is highly region-specific, ${ }^{3}$ they have in common that the large majority of the gap is unexplained. Moreover, human capital contributes very little to the explained and unexplained gaps. The greatest impact of differences in human capital is found for immigrants originating from Africa.

The pattern of large unexplained gaps also holds across different source regions for each separate intake category. Moreover the category hierarchy of gap sizes according to intake category is also robust to the source region, so that labor immigrants in particular have a considerably smaller employment gap. Finally, the limited contribution of human capital is also generally affirmed in subsamples of intake category and regional origin. However, there are larger contributions for immigrants from source regions with a pronounced employment gap, like family and humanitarian immigrants from Africa (35 and $25 \%$ ) and family immigrants from the Middle East (23\%).

Overall, our benchmark results are confirmed for a large number of regional subsamples. Hence, our results are not driven by unobserved heterogeneity related to source regions. Africa aside, human capital endowment and returns explain only a small share of employment differences for all intake categories. Again, the sheer group membership or intake classification, along with related unobservables, play an important role

\subsection{Country-specific human capital}

Another potential source of unobserved heterogeneity is related to age at migration. However, it does not only check for unobserved heterogeneity, but also allows us to test whether the role of human capital might change according to the different origins of human capital. By comparing immigrants of different ages at immigration we can artificially distinguish individuals with almost-certain Swedish human capital, education and language skills, and their counterparts who pursued most of their education abroad and have uncertain host-country language skills. In particular, we compare immigrants who arrived before the age of ten with their complement. Consequently, we would expect employment to be higher for the group of early-life migrants. Obviously this shifts our analysis from focusing on an immigrant-native gap to explaining different employment rates within each immigration group. As a positive side effect, our groups of early- and late-age immigrants are more homogenous and, hence, the omitted variable bias should be reduced substantially. In order to control for differences in experience, we include a measure for years since migration. Due to the early arrival age, we have to limit our analysis to family and humanitarian immigrants. Table 5 shows the results of this immigrant-immigrant decomposition. Again, each column refers to a different employment gap and Panel 1 displays the decomposition into an explained and an unexplained gap. In line with our benchmark decomposition in Table 4, Panels 2 and 3 deliver the detailed decomposition for the explained and unexplained gaps, respectively.

\footnotetext{
${ }^{3}$ The employment rate of immigrants from the Middle East and Africa is 34 percentage points lower than for their native counterparts. However, for European immigrants the raw gap is only 14 percentage points.
} 
Table 5 Non-linear decomposition: age at immigration $<=10$

\begin{tabular}{|c|c|c|c|}
\hline & Immigrant & Family & Humanitarian \\
\hline \multicolumn{4}{|l|}{ Panel 1 Overall } \\
\hline \multirow[t]{2}{*}{ Immigrant $(<=10)$} & $0.70^{* * *}$ & $0.64^{* * *}$ & $0.72^{* * *}$ \\
\hline & $(0.01)$ & $(0.01)$ & $(0.01)$ \\
\hline \multirow[t]{2}{*}{ Immigrant (>10) } & $0.62^{* * *}$ & $0.64^{* * *}$ & $0.61^{* * *}$ \\
\hline & $(0.00)$ & $(0.00)$ & $(0.00)$ \\
\hline \multirow[t]{2}{*}{ Difference } & $0.08^{* * *}$ & 0.00 & $0.12^{* * *}$ \\
\hline & $(0.01)$ & $(0.01)$ & $(0.01)$ \\
\hline \multirow[t]{2}{*}{ Explained } & $0.13^{* * *}$ & $0.09^{* * *}$ & $0.14^{* * *}$ \\
\hline & $(0.00)$ & $(0.01)$ & $(0.00)$ \\
\hline \multirow[t]{2}{*}{ Unexplained } & $-0.04^{* * *}$ & $-0.09^{* * *}$ & $-0.03^{* * *}$ \\
\hline & $(0.01)$ & $(0.01)$ & $(0.01)$ \\
\hline \multicolumn{4}{|l|}{ Panel 2 Explained } \\
\hline \multirow[t]{2}{*}{ Controls } & $-0.03^{* * *}$ & $-0.04^{* * *}$ & $-0.03^{* * *}$ \\
\hline & $(0.00)$ & $(0.00)$ & $(0.00)$ \\
\hline \multirow[t]{2}{*}{ Education } & $0.02^{* * *}$ & $0.02^{* * *}$ & $0.02^{* * *}$ \\
\hline & $(0.00)$ & $(0.00)$ & $(0.00)$ \\
\hline \multirow[t]{2}{*}{ Education type } & $0.01^{* * *}$ & $0.01^{* * *}$ & $0.01^{* * *}$ \\
\hline & $(0.00)$ & $(0.00)$ & $(0.00)$ \\
\hline \multirow[t]{2}{*}{ Years since migration } & $0.10^{* * *}$ & $0.12^{* * *}$ & $0.10^{* * *}$ \\
\hline & $(0.00)$ & $(0.00)$ & $(0.00)$ \\
\hline \multirow[t]{2}{*}{ Source } & $0.02^{* * *}$ & $-0.01^{* * *}$ & $0.04^{* * *}$ \\
\hline & $(0.00)$ & $(0.00)$ & $(0.00)$ \\
\hline \multicolumn{4}{|l|}{ Panel 3 Unexplained } \\
\hline \multirow[t]{2}{*}{ Controls } & $-0.05^{*}$ & -0.05 & -0.07 \\
\hline & $(0.02)$ & $(0.04)$ & $(0.04)$ \\
\hline \multirow[t]{2}{*}{ Education } & $0.04^{* * *}$ & 0.02 & $0.06^{* *}$ \\
\hline & $(0.01)$ & $(0.01)$ & $(0.02)$ \\
\hline \multirow[t]{2}{*}{ Education type } & 0.02 & 0.00 & $0.03^{*}$ \\
\hline & $(0.01)$ & $(0.02)$ & $(0.02)$ \\
\hline \multirow[t]{2}{*}{ Years since migration } & -0.09 & 0.14 & -0.30 \\
\hline & $(0.12)$ & $(0.18)$ & $(0.22)$ \\
\hline \multirow[t]{2}{*}{ Source } & $0.09^{*}$ & 0.04 & 0.05 \\
\hline & $(0.04)$ & $(0.04)$ & $(0.03)$ \\
\hline \multirow[t]{2}{*}{ Constant } & -0.05 & -0.24 & 0.20 \\
\hline & $(0.14)$ & $(0.19)$ & $(0.23)$ \\
\hline$N$ & 113,497 & 28,222 & 82,518 \\
\hline
\end{tabular}

Notes: Robust standard errors in parentheses; ${ }^{*} p<0.05,{ }^{* *} p<0.01,{ }^{* * *} p<0.001$

As expected, Panel 1 reports a higher employment rate for early-life immigrants. In line with the theory, important drivers of the gap are not only their higher endowment but particularly their returns to human capital attainment. In column 1 of the second panel we find differences in educational attainment which explain roughly $25 \%(0.02 / 0.08)$ of the respective employment gap and its related lower returns to amount to $50 \%(0.04 / 0.08)$ of the raw gap. In particular, the latter result indicates that the lack of country-specific human capital could explain parts of the large employment gap across intake categories. Moreover, it explains the low impact of human capital characteristics and its return. It seems as if humanitarian and family immigrants at later ages have a lower educational attainment and a less-favorable specialization. Remarkably, both findings hold true even though we control for their difference in the number of years since migration. Interestingly, columns 2 and 3 indicate that most of the higher country-specific human capital returns stem from humanitarian immigrants, as the difference between young and old immigrants is not significant for family migrants. 


\section{Concluding discussion}

The aim of this article has been to study the extent to which human capital characteristics, operationalized as level and field of education, and migrant categories explain the immigrantnative employment gap in Sweden. Employing a decomposition analysis and using highquality register data for the year 2011, including a wide range of individual demographic and socio-economic covariates as well as the admission status of the immigrants, we have added to existing knowledge on the employment integration of immigrants in host countries.

Earlier research on the employment integration of immigrants has highlighted human capital as an important factor (Bevelander 2011; Chiswick and Miller 2009). Other studies have shown that it is not only formal education and skills which matter but that who migrates to another country and why are also of importance, i.e. selection through migration category (Aydemir 2011; Bevelander 2011; Borjas 1994; Chiswick et al 2005). In this study we have operationalized human capital as education level and education field, and show that these factors are not only in line with earlier studies (Dahlstedt and Bevelander 2010), but are also important for explaining employment levels within each migrant category. To have at least a three-year secondary education is essential for migrants' employment success. However, a higher education level than this does not, on average, improve migrants' employment levels. More importantly, differences in education level and field only explain a small part of the employment gap between natives and migrants. Human capital characteristics explain about 5 percentage points, one fifth, of the gap between natives and family ( 24 percentage points) and humanitarian (27 percentage points) migrants. After controlling for human capital, demographic and contextual factors, we find that the employment gap is lowest for labor migrants (10 \%), and substantially larger for family (24\%) and humanitarian (29\%) migrants, which is in line with earlier studies for Sweden (Bevelander 2011) and Canada (Aydemir 2011). Subsequently, controlling for observable factors increases the employment-level differences for family and humanitarian migrants. A surprising result is that, when controlling for demographic, contextual and educational factors, we find an increase in the employment gap for labor migrants. Overall, the employment gaps and limited role of human capital in explaining them could also be found in various non-linear decomposition exercises.

The results clearly show the difficulties faced by humanitarian and family migrants trying to utilize their educational human capital on the Swedish labor market. This could be a sign of the lower quality of education obtained in their origin country, but might also be connected to the weaker transferability of foreign qualifications. When we study the group of migrants who have pursued most or all of their education in Sweden, we find that differences in human capital explain more of the employment gap and that their human capital has a higher return on the labour market compared to the immigrant group as a whole.

Decomposition analysis reveals that other factors than human capital also help to explain some of the employment gap. In particular the distribution of and return on marital status, the number of children, and living in the county of Stockholm explain part of the labor migrantnative employment gap. In contrast, humanitarian immigrants' socio-demographic characteristics actually shrink the employment gap, while their lower returns explain a sizable $17 \%$ of the overall gap. Finally, contextual factors help to explain the integration differences between early- and later-life immigrants. In particular, while average years since migration explain at least $70 \%$ of the employment gap among all intake categories, the differential source regions of early- and later-age migrants drives $28 \%$ of the gap for humanitarian immigrants.

All in all, our findings indicate that migrant category is a very important factor in explaining native-immigrant employment gaps. Human capital, and demographic and contextual factors only explain a small part of the gap. It is clear that humanitarian and family migrants have less transferable human capital compared to labor migrants. Another possible explanations for the 
gap could be socio-cultural factors (Koopmans 2016). However, socio-cultural factors do not seem to be an issue for labor migrants.

From a policy perspective, considering the high levels of immigration of humanitarian and family migrants to Sweden in recent years, the challenge for the Swedish labor market is to increase the transferability of skills of those having medium and high levels of education, as well as to offer the possibility for lesser-skilled individuals to upgrade their qualifications in order to enter the labor market.

\section{References}

Abdulloev I, Gang I, Yun M-S (2014) Migration, education and the gender gap in labour force participation. European Journal of Development Research 26:509-526

Antecol H (2001) Why is there interethnic variation in the gender wage gap? The role of cultural factors. Journal of Human Resources 36(1):119-143

Aydemir A (2011) Immigrant selection and short-term labor market outcomes by visa category. Journal of Population Economics 24(2):451-475

Becker GS (1992) Human capital and the economy. Proceedings of the American Philosophical Society 136(1):85-92

Bevelander P (2005) The employment status of immigrant women: the case of Sweden. International Migration Review 39(1):173-202

Bevelander P (2011) The employment integration of resettled refugees, asylum claimants, and family reunion migrants in Sweden. Refugee Survey Quarterly 30(1):22-43

Bevelander P, Groeneveld S (2006) Patterns of transition: female native Dutch and ethnic minority employment patterns in the Dutch labour market, 1991 and 2002. Journal of Ethnic and Migration Studies 32(5):785-807

Bevelander P, Pendakur R (2014) The labour market integration of refugee and family reunion immigrants: a comparison of outcomes in Canada and Sweden. Journal of Ethnic and Migration Studies 40(5):689-709

Bitoulas A (2015) Asylum applicants and first instance decisions on asylum applications: 2014. Eurostat Data in Focus 3

Borevi K (2014) Family migration policies and politics understanding the Swedish exception. Journal of Family Issues 36(11:1490-1508

Borjas GJ (1994) The economics of immigration. Journal of Economic Literature 32(4):1667-1717

Chiswick B, Miller PW (1992) Post-immigration qualifications in Australia: determinants and consequences. Bureau of Immigration and Population Research, Australian Government Printing Service, Canberra

Chiswick BR, Miller PW (2009) The international transferability of immigrants' human capital. Economics of Education Review 28(2):162-169

Chiswick B, Liang Lee Y, Miller PW (2005) A longitudinal analysis of immigrant occupational mobility: a test of the immigrant assimilation hypothesis. International Migration Review 39(2):332-353

Cobb-Clark DA (2000) Do selection criteria make a difference? Visa category and the labour market status of immigrants to Australia. Econ Rec 76(232):15-31

Connor P. (2010) Explaining the refugee gap: economic outcomes of refugees versus other immigrants. Journal of Refugee Studies 23(3):377-397

Constant A, Zimmermann KF (2005) Immigrant performance and selective immigration policy: a European perspective. Natl Econ Rev 194(1):94-105 
Dahlstedt I, Bevelander B (2010) General versus vocational education and employment integration of immigrants in Sweden, Journal of Immigrant and Refugee Studies 8(2):158-192

De Silva A (1997) Earnings of immigrant classes in the early 1980s in Canada: a reexamination. Can Public Policy 23(2):179-202

DeVoretz DJ, Pivnenko S, Beiser M (2004) The economic experiences of refugees in Canada. IZA discussion paper 1088, Bonn

Emilsson H (2016) Recruitment to occupations with a surplus of workers: the unexpected outcomes of Swedish demand-driven labour migration policy. International Migration 54(1):5-17

Emilsson H, Magnusson K (2015) Högkvalificerad arbetskraftsinvandring till Sverige. In: Calleman C, Herzfeld Olsson P (eds) Arbetskraft från hela världen: hur blev det med 2008 års reform?, Delmi Rapport nr: 2015:9, Stockholm, pp 72-113

Eriksson S (2010) Utrikes födda på den svenska arbetsmarknaden. In: Vägen till arbete Arbetsmarknadspolitik, utbildning och arbetsmarknadsintegration. Bilaga 4 till Långtidsutredningen 2011, SOU 2010:88. Fritzes, Stockholm, pp 243-389

Eurostat (2014) Residence permits for non-EU citizens in the EU28, Eurostat newsrelease $159 / 2014$

Friedberg R (2000) You can't take it with you? Immigrant assimilation and the portability of human capital. Journal of Labor Economics 18(2):221-251

Jann B (2008) The Blinder-Oaxaca decomposition for linear regression models. The Stata Journal 8(4):453-479

Jasso G, Rosenzweig M (1995) Do immigrants screened for skills do better than family reunification immigrants? International Migration Review 29(1):85-111

Koopmans R (2016) Does assimilation work? Sociocultural determinants of labour market participation of European Muslims. Journal of Ethnic and Migration Studies 42(2):197216

MIPEX (2015) Labour market mobility. http://www.mipex.eu/labour-market-mobility. Accessed 30 April 2016

Nordin M (2007) Invandrares avkastning på utbildning i Sverige. IFAU Rapport 2007:10, Institutet för arbetsmarknadspolitisk utvärdering, Uppsala

Oaxaca R, Ransom M (1999) Identification in detailed wages decompositions. Review of Economics and Statistics 81(1):154-157

OECD (2011) Recruiting immigrant workers: Sweden 2011. OECD Publishing, Paris

OECD (2014) International migration outlook 2014. OECD Publishing, Paris

OECD/European Union (2015) Indicators of immigrant integration 2015: settling in. OECD Publishing, Paris.

Statistics Sweden (2012) Theme: education adult learning 2010. Theme report 2012:1. Statistics Sweden, Stockholm

Szulkin R, Nekby L, Bygren M, Lindblom C, Russell-Jonsson K, Bengtsson R, Normark E (2013) På jakt efter framgångsrik arbetslivsintegrering. Institutet för Framtidsstudier, Stockholm

Wooden M (1990) Migrant labour market status. Bureau of Immigration Research, Australian Government Printing Service, Canberra

Yun M-S (2004) Decomposing differences in the first moment. Economics Letters 82(2):275-280

Yun M-S (2005) A simple solution to the identification problem in detailed wage decompositions. Economic Inquiry 43(4):766-772 


\section{Appendix}

Table 6 Probit model coefficient on employment

\begin{tabular}{|c|c|c|c|c|c|}
\hline & Native & Immigrant & $\begin{array}{c}\text { Immigrant } \\
\text { (labor) }\end{array}$ & $\begin{array}{c}\text { Immigrant } \\
\text { (family) }\end{array}$ & $\begin{array}{c}\text { Immigrant } \\
\text { (humanitarian) }\end{array}$ \\
\hline \multicolumn{6}{|l|}{ Employed } \\
\hline \multirow[t]{2}{*}{ Age 30-39 } & $0.33^{* * *}$ & -0.01 & $-0.21^{* *}$ & 0.03 & -0.02 \\
\hline & $(0.00)$ & $(0.01)$ & $(0.07)$ & $(0.02)$ & $(0.01)$ \\
\hline \multirow[t]{2}{*}{ Age $40-49$} & $0.34^{* * *}$ & $-0.07^{* * *}$ & $-0.44^{* * *}$ & $0.08^{* * *}$ & $-0.11^{* * *}$ \\
\hline & $(0.00)$ & $(0.01)$ & $(0.09)$ & $(0.02)$ & $(0.02)$ \\
\hline \multirow[t]{2}{*}{ Age 50-59 } & $0.20^{* * *}$ & $-0.30^{* * *}$ & $-0.59^{* * *}$ & $-0.25^{* * *}$ & $-0.30^{* * * *}$ \\
\hline & $(0.00)$ & $(0.01)$ & $(0.11)$ & $(0.03)$ & $(0.02)$ \\
\hline \multirow[t]{2}{*}{ Single } & $-0.52^{* * *}$ & $-0.20^{* * *}$ & $-0.15^{*}$ & $-0.22^{* * *}$ & $-0.20^{* * *}$ \\
\hline & $(0.00)$ & $(0.01)$ & (0.07) & $(0.02)$ & $(0.01)$ \\
\hline \multirow[t]{2}{*}{ Divorced } & $-0.42^{* * *}$ & $-0.23^{* * * *}$ & $0.29^{*}$ & $-0.24^{* * * *}$ & $-0.23^{* * *}$ \\
\hline & $(0.00)$ & $(0.01)$ & $(0.12)$ & $(0.02)$ & $(0.01)$ \\
\hline \multirow[t]{2}{*}{ Widowed } & $-0.33^{* * *}$ & $-0.34^{* * *}$ & 0.17 & $-0.47^{* * *}$ & $-0.31^{* * *}$ \\
\hline & $(0.02)$ & $(0.06)$ & $(0.44)$ & $(0.14)$ & $(0.07)$ \\
\hline \multirow[t]{2}{*}{ Children } & $0.14^{* * *}$ & $0.02^{* * *}$ & $0.24^{* * *}$ & $0.05^{* * *}$ & $0.01^{* * *}$ \\
\hline & $(0.00)$ & $(0.00)$ & (0.04) & $(0.01)$ & $(0.00)$ \\
\hline \multirow[t]{2}{*}{ County03 } & $-0.05^{* * *}$ & $-0.20^{* * *}$ & -0.02 & $-0.12^{* *}$ & $-0.23^{* * *}$ \\
\hline & $(0.01)$ & $(0.02)$ & $(0.14)$ & $(0.04)$ & $(0.03)$ \\
\hline \multirow[t]{2}{*}{ County04 } & $-0.04^{* * *}$ & $-0.39^{* * *}$ & 0.46 & $-0.38^{* * *}$ & $-0.38^{* * *}$ \\
\hline & $(0.01)$ & $(0.02)$ & $(0.28)$ & $(0.05)$ & $(0.03)$ \\
\hline \multirow[t]{2}{*}{ County05 } & $-0.10^{* * *}$ & $-0.35^{* * *}$ & -0.07 & $-0.33^{* * *}$ & $-0.34^{* * *}$ \\
\hline & $(0.01)$ & $(0.02)$ & $(0.15)$ & $(0.04)$ & $(0.02)$ \\
\hline \multirow[t]{2}{*}{ County06 } & $0.11^{* * *}$ & $0.07^{* * *}$ & 0.16 & 0.06 & $0.09^{* * *}$ \\
\hline & $(0.01)$ & $(0.02)$ & $(0.28)$ & $(0.05)$ & $(0.02)$ \\
\hline \multirow[t]{2}{*}{ County07 } & $0.11^{* * *}$ & $-0.17^{* * *}$ & 0.20 & $-0.21^{* *}$ & $-0.16^{* * *}$ \\
\hline & $(0.01)$ & $(0.03)$ & $(0.28)$ & $(0.07)$ & $(0.03)$ \\
\hline \multirow[t]{2}{*}{ County08 } & $-0.03^{* * *}$ & $-0.07^{*}$ & -0.35 & 0.05 & $-0.08^{*}$ \\
\hline & $(0.01)$ & $(0.03)$ & $(0.30)$ & $(0.08)$ & $(0.04)$ \\
\hline \multirow[t]{2}{*}{ County09 } & $-0.11^{* * *}$ & $-0.43^{* * * *}$ & -1.13 & -0.29 & $-0.51^{* * *}$ \\
\hline & $(0.02)$ & $(0.11)$ & $(0.85)$ & $(0.16)$ & $(0.15)$ \\
\hline \multirow[t]{2}{*}{ County10 } & $-0.08^{* * *}$ & $-0.38^{* * *}$ & -0.32 & $-0.44^{* * *}$ & $-0.36^{* * *}$ \\
\hline & $(0.01)$ & $(0.04)$ & $(0.24)$ & $(0.09)$ & $(0.04)$ \\
\hline \multirow[t]{2}{*}{ County12 } & $-0.19^{* * *}$ & $-0.35^{* * *}$ & $-0.21^{*}$ & $-0.41^{* * *}$ & $-0.32^{* * *}$ \\
\hline & $(0.00)$ & $(0.01)$ & (0.09) & $(0.02)$ & $(0.01)$ \\
\hline \multirow{2}{*}{ County13 } & $0.06^{* * *}$ & 0.04 & -0.40 & -0.06 & $0.09^{* *}$ \\
\hline & $(0.01)$ & $(0.03)$ & $(0.22)$ & $(0.06)$ & $(0.03)$ \\
\hline \multirow[t]{2}{*}{ County14 } & $-0.07^{* * *}$ & $-0.20^{* * *}$ & -0.01 & $-0.21^{* * *}$ & $-0.19^{* * *}$ \\
\hline & $(0.00)$ & $(0.01)$ & $(0.08)$ & $(0.02)$ & $(0.01)$ \\
\hline \multirow[t]{2}{*}{ County17 } & $-0.26^{* * *}$ & $-0.26^{* * *}$ & -0.18 & $-0.38^{* * *}$ & $-0.21^{* * *}$ \\
\hline & $(0.01)$ & $(0.03)$ & $(0.24)$ & $(0.07)$ & $(0.04)$ \\
\hline County18 & $-0.06^{* * *}$ & $-0.22^{* * *}$ & 0.14 & $-0.20^{* * *}$ & $-0.21^{* * *}$ \\
\hline & $(0.01)$ & $(0.02)$ & $(0.31)$ & $(0.05)$ & $(0.03)$ \\
\hline County19 & $-0.07^{* * *}$ & $-0.18^{* * *}$ & $0.76^{* *}$ & $-0.21^{* * *}$ & $-0.17^{* * *}$ \\
\hline & $(0.01)$ & $(0.02)$ & $(0.24)$ & $(0.05)$ & $(0.03)$ \\
\hline County20 & $-0.08^{* * *}$ & $-0.36^{* * *}$ & 0.32 & $-0.40^{* * *}$ & $-0.36^{* * *}$ \\
\hline & $(0.01)$ & $(0.03)$ & $(0.20)$ & $(0.07)$ & $(0.04)$ \\
\hline County21 & $-0.06^{* * *}$ & $-0.46^{* * *}$ & 0.15 & $-0.33^{* * *}$ & $-0.49^{* * *}$ \\
\hline & $(0.01)$ & $(0.03)$ & $(0.24)$ & $(0.06)$ & $(0.03)$ \\
\hline County22 & $-0.09^{* * *}$ & $-0.40^{* * *}$ & 0.17 & $-0.33^{* * *}$ & $-0.43^{* * *}$ \\
\hline & $(0.01)$ & $(0.04)$ & $(0.27)$ & $(0.08)$ & $(0.04)$ \\
\hline County23 & $-0.11^{* * *}$ & $-0.41^{* * *}$ & -0.02 & -0.16 & $-0.51^{* * *}$ \\
\hline & $(0.01)$ & $(0.06)$ & $(0.31)$ & (0.13) & $(0.07)$ \\
\hline County24 & $-0.11^{* * *}$ & $-0.33^{* * *}$ & -0.22 & -0.12 & $-0.39^{* * *}$ \\
\hline
\end{tabular}




\begin{tabular}{|c|c|c|c|c|c|}
\hline \multirow{3}{*}{ County25 } & $(0.01)$ & $(0.04)$ & $(0.18)$ & $(0.07)$ & $(0.04)$ \\
\hline & $-0.09^{* * *}$ & $-0.22^{* * * *}$ & 0.12 & $-0.25^{* *}$ & $-0.22^{* * *}$ \\
\hline & $(0.01)$ & $(0.05)$ & $(0.24)$ & $(0.09)$ & $(0.06)$ \\
\hline \multirow{2}{*}{ Pre-sec. 9} & $0.34^{* * * *}$ & $0.23^{* * * *}$ & -0.25 & $0.22^{* * *}$ & $0.23^{* * *}$ \\
\hline & $(0.01)$ & $(0.01)$ & $(0.19)$ & $(0.03)$ & $(0.02)$ \\
\hline \multirow[t]{2}{*}{ Secondary $<3$} & $0.43^{* * *}$ & $0.40^{* * * *}$ & -0.24 & $0.32^{* * *}$ & $0.43^{* * *}$ \\
\hline & $(0.01)$ & $(0.02)$ & $(0.20)$ & $(0.03)$ & $(0.02)$ \\
\hline \multirow[t]{2}{*}{ Secondary 3} & $0.78^{* * *}$ & $0.60^{* * * *}$ & -0.25 & $0.50^{* * * *}$ & $0.63^{* * * *}$ \\
\hline & $(0.01)$ & $(0.02)$ & $(0.21)$ & $(0.03)$ & $(0.02)$ \\
\hline \multirow[t]{2}{*}{ Post-sec. $<3$} & $0.62^{* * *}$ & $0.30^{* * * *}$ & 0.06 & $0.23^{* * *}$ & $0.30^{* * * *}$ \\
\hline & $(0.01)$ & $(0.02)$ & $(0.23)$ & $(0.04)$ & $(0.02)$ \\
\hline \multirow{2}{*}{ Post-sec. $>=3$} & $0.83^{* * *}$ & $0.45^{* * * *}$ & -0.09 & $0.40^{* * * *}$ & $0.44^{* * *}$ \\
\hline & $(0.01)$ & $(0.02)$ & $(0.22)$ & $(0.04)$ & $(0.02)$ \\
\hline \multirow[t]{2}{*}{ Scientific } & $0.92^{* * *}$ & $0.55^{* * * *}$ & -0.17 & $0.47^{* * *}$ & $0.48^{* * *}$ \\
\hline & $(0.02)$ & $(0.04)$ & $(0.23)$ & $(0.07)$ & $(0.06)$ \\
\hline \multirow[t]{2}{*}{ Pedagogics } & $0.20^{* * * *}$ & $0.16^{* * * *}$ & 0.01 & $0.17^{* *}$ & $0.18^{* * * *}$ \\
\hline & $(0.01)$ & $(0.03)$ & $(0.26)$ & $(0.06)$ & $(0.03)$ \\
\hline \multirow[t]{2}{*}{ Humanities } & $-0.18^{* * * *}$ & $-0.07^{* *}$ & 0.10 & -0.00 & $-0.11^{* * *}$ \\
\hline & $(0.01)$ & $(0.02)$ & $(0.21)$ & $(0.04)$ & $(0.03)$ \\
\hline \multirow[t]{2}{*}{ Social sciences } & $0.06^{* * * *}$ & $0.11^{* * * *}$ & -0.09 & $0.08^{*}$ & $0.14^{* * * *}$ \\
\hline & $(0.01)$ & $(0.02)$ & $(0.19)$ & $(0.04)$ & $(0.02)$ \\
\hline \multirow[t]{2}{*}{ Natural sciences } & $-0.02^{*}$ & $0.14^{* * * *}$ & 0.13 & $0.15^{* * *}$ & $0.11^{* * * *}$ \\
\hline & $(0.01)$ & $(0.02)$ & $(0.18)$ & $(0.04)$ & $(0.03)$ \\
\hline \multirow[t]{2}{*}{ Technical } & $0.26^{* * *}$ & $0.29^{* * * *}$ & $0.38^{*}$ & $0.27^{* * *}$ & $0.29^{* * *}$ \\
\hline & $(0.01)$ & $(0.01)$ & $(0.18)$ & $(0.03)$ & $(0.02)$ \\
\hline \multirow[t]{2}{*}{ Agriculture } & $0.35^{* * *}$ & $0.17^{* * *}$ & 0.20 & $0.21^{* *}$ & $0.18^{* * * *}$ \\
\hline & $(0.01)$ & $(0.04)$ & $(0.33)$ & $(0.08)$ & $(0.04)$ \\
\hline \multirow[t]{2}{*}{ Health } & $0.09^{* * * *}$ & $0.39^{* * *}$ & -0.14 & $0.26^{* * *}$ & $0.48^{* * * *}$ \\
\hline & $(0.01)$ & $(0.02)$ & $(0.20)$ & $(0.04)$ & $(0.03)$ \\
\hline \multirow[t]{2}{*}{ Services } & $0.21^{* * * *}$ & $0.19^{* * *}$ & -0.18 & $0.17^{* * * *}$ & $0.20^{* * *}$ \\
\hline & $(0.01)$ & $(0.02)$ & $(0.22)$ & $(0.04)$ & $(0.03)$ \\
\hline \multirow[t]{2}{*}{ Type unknown } & $0.06^{* * *}$ & $0.11^{* * *}$ & -0.20 & 0.04 & $0.15^{* * *}$ \\
\hline & $(0.01)$ & $(0.02)$ & $(0.18)$ & $(0.04)$ & $(0.02)$ \\
\hline \multirow[t]{2}{*}{ Constant } & $0.54^{* * * *}$ & $0.17^{* * * *}$ & $1.04^{* * * *}$ & $0.17^{* * * *}$ & $0.15^{* * * *}$ \\
\hline & $(0.01)$ & $(0.02)$ & $(0.15)$ & $(0.03)$ & $(0.02)$ \\
\hline$N$ & $\begin{array}{l}1,699,060 \\
\end{array}$ & 117,049 & 3,247 & 29,193 & 84,609 \\
\hline Pseudo $R^{2}$ & 0.094 & 0.050 & 0.068 & 0.047 & 0.054 \\
\hline \multirow[t]{2}{*}{ Log-Lik. } & - & $-73,414.58$ & $-1,480.64$ & $-18,192.87$ & $-53,324.91$ \\
\hline & $557,372.61$ & & & & \\
\hline Chi2 & $93,367.48$ & $7,504.29$ & 200.60 & $1,694.84$ & $5,830.17$ \\
\hline
\end{tabular}

Notes: Robust standard errors in parentheses; ${ }^{*} p<0.05,{ }^{* *} p<0.01,{ }^{* * *} p<0.001$

Table 7 Employment rate by educational attainment

\begin{tabular}{lccccc}
\hline Educational attainment & Native & Immigrant & $\begin{array}{c}\text { Immigrant } \\
\text { (labor) }\end{array}$ & $\begin{array}{c}\text { Immigrant } \\
\text { (family) }\end{array}$ & $\begin{array}{c}\text { Immigrant } \\
\text { (humanitarian) }\end{array}$ \\
\hline Pre-secondary $<9$ & 65.50 & 44.64 & 81.62 & 49.20 & 43.10 \\
Pre-secondary 9 & 78.34 & 53.86 & 73.33 & 56.84 & 52.33 \\
Secondary $<3$ & 87.79 & 65.33 & 74.03 & 65.46 & 65.19 \\
Secondary 3 & 90.34 & 71.96 & 71.43 & 71.25 & 72.18 \\
Post-secondary $<3$ & 89.21 & 62.96 & 85.53 & 62.85 & 61.84 \\
Post-secondary $>=3$ & 92.54 & 68.55 & 81.64 & 69.51 & 66.88 \\
Scientific & 95.16 & 73.63 & 78.09 & 73.70 & 69.67 \\
\hline
\end{tabular}


Table 8 Employment rate by education type

\begin{tabular}{lccccc}
\hline Education type & Native & Immigrant & $\begin{array}{c}\text { Immigrant } \\
\text { (labor) }\end{array}$ & $\begin{array}{c}\text { Immigrant } \\
\text { (family) }\end{array}$ & $\begin{array}{c}\text { Immigrant } \\
\text { (humanitarian) }\end{array}$ \\
\hline General & 80.34 & 53.06 & 76.76 & 56.66 & 51.61 \\
Pedagogics & 92.68 & 65.01 & 76.00 & 67.52 & 64.09 \\
Humanities & 81.39 & 58.31 & 78.15 & 61.86 & 55.82 \\
Social sciences & 89.65 & 65.01 & 76.37 & 65.17 & 64.45 \\
Natural sciences & 88.16 & 66.78 & 80.66 & 68.09 & 63.77 \\
Technical & 91.05 & 71.63 & 87.78 & 71.63 & 70.65 \\
Agriculture & 92.41 & 66.56 & 80.00 & 69.77 & 65.24 \\
Health & 89.75 & 74.99 & 71.81 & 71.58 & 76.33 \\
Services & 89.86 & 67.68 & 73.42 & 67.44 & 67.64 \\
Unknown & 88.18 & 64.72 & 69.46 & 64.01 & 64.79 \\
\hline
\end{tabular}

Table 9 Probability model of employment: pooled by intake category

\begin{tabular}{|c|c|c|c|c|}
\hline \multicolumn{5}{|c|}{ All } \\
\hline \multirow[t]{2}{*}{ Labor immigrants } & $-0.07^{* * *}$ & $-0.09^{* * *}$ & $-0.10^{* * *}$ & $-0.10^{* * *}$ \\
\hline & $(0.01)$ & $(0.01)$ & $(0.01)$ & $(0.01)$ \\
\hline \multirow[t]{2}{*}{ Family immigrants } & $-0.24^{* * *}$ & $-0.29^{* * *}$ & $-0.26^{* * *}$ & $-0.24^{* * *}$ \\
\hline & $(0.00)$ & $(0.00)$ & $(0.00)$ & $(0.00)$ \\
\hline \multirow[t]{2}{*}{ Humanitarian immigrants } & $-0.27^{* * *}$ & $-0.34^{* * *}$ & $-0.30^{* * *}$ & $-0.29^{* * *}$ \\
\hline & $(0.00)$ & $(0.00)$ & $(0.00)$ & $(0.00)$ \\
\hline$N$ & $1,816,109$ & $1,816,109$ & $1,816,109$ & $1,816,109$ \\
\hline Pseudo $R^{2}$ & 0.033 & 0.086 & 0.106 & 0.112 \\
\hline Log-Lik. & $-692,061.20$ & $-653,954.18$ & $-639,206.09$ & $-634,990.51$ \\
\hline Chi2 & $48,539.85$ & $112,926.44$ & $132,655.49$ & $139,294.19$ \\
\hline \multicolumn{5}{|c|}{ Immigrant (labor) } \\
\hline \multirow[t]{2}{*}{ Labor immigrants } & $-0.07^{* * *}$ & $-0.09^{* * *}$ & $-0.10^{* * *}$ & $-0.10^{* * *}$ \\
\hline & $(0.01)$ & $(0.01)$ & $(0.01)$ & $(0.01)$ \\
\hline$N$ & $1,702,307$ & $1,702,307$ & $1,702,307$ & $1,702,307$ \\
\hline Pseudo $R^{2}$ & 0.000 & 0.066 & 0.087 & 0.093 \\
\hline Log-Lik. & $-616,630.74$ & $-576,201.65$ & $-562,950.19$ & $-559,096.08$ \\
\hline Chi2 & 157.05 & $67,804.56$ & $87,981.84$ & $93,554.03$ \\
\hline \multicolumn{5}{|c|}{ Immigrant (family) } \\
\hline \multirow[t]{2}{*}{ Family immigrants } & $-0.24^{* * *}$ & $-0.30^{* * *}$ & $-0.26^{* * *}$ & $-0.24^{* * *}$ \\
\hline & $(0.00)$ & $(0.00)$ & $(0.00)$ & $(0.00)$ \\
\hline$N$ & $1,728,253$ & $1,728,253$ & $1,728,253$ & $1,728,253$ \\
\hline Pseudo $R^{2}$ & 0.009 & 0.072 & 0.093 & 0.099 \\
\hline Log-Lik. & $-634,125.92$ & $-593,890.90$ & $-580,460.03$ & $-576,533.35$ \\
\hline Chi2 & $11,900.31$ & $78,943.41$ & $98,271.55$ & $104,176.51$ \\
\hline \multicolumn{5}{|c|}{ Immigrant (humanitarian) } \\
\hline \multirow[t]{2}{*}{ Humanitarian immigrant } & $-0.27^{* * *}$ & $-0.34^{* * *}$ & $-0.30^{* * *}$ & $-0.29^{* * *}$ \\
\hline & $(0.00)$ & $(0.00)$ & $(0.00)$ & $(0.00)$ \\
\hline$N$ & $1,783,669$ & $1,783,669$ & $1,783,669$ & $1,783,669$ \\
\hline Pseudo $R^{2}$ & 0.027 & 0.082 & 0.103 & 0.109 \\
\hline Log-Lik. & $-671,388.09$ & $-633,132.69$ & $-618,493.86$ & $-614,392.23$ \\
\hline Chi2 & $38,394.64$ & $102,446.91$ & $122,197.67$ & $128,637.50$ \\
\hline \multicolumn{5}{|c|}{ Controls } \\
\hline Demographic & No & Yes & Yes & Yes \\
\hline Education & No & No & Yes & Yes \\
\hline Education type & No & No & No & Yes \\
\hline
\end{tabular}


Table 10 Non-linear decomposition analysis: detail

\begin{tabular}{|c|c|c|c|c|}
\hline & Immigrant-Native & $\begin{array}{l}\text { Labor immigrant- } \\
\text { Native } \\
\end{array}$ & $\begin{array}{c}\text { Family immigrant- } \\
\text { Native }\end{array}$ & $\begin{array}{c}\text { Humanitarian } \\
\text { immigrant-Native }\end{array}$ \\
\hline \multicolumn{5}{|l|}{ Overall } \\
\hline Native & $\begin{array}{c}0.88^{* * *} \\
(0.00)\end{array}$ & $\begin{array}{c}0.88^{* * *} \\
(0.00)\end{array}$ & $\begin{array}{c}0.88^{* * *} \\
(0.00)\end{array}$ & $\begin{array}{c}0.88^{* * *} \\
(0.00)\end{array}$ \\
\hline Immigrant & $\begin{array}{c}0.63^{* * *} \\
(0.00)\end{array}$ & $\begin{array}{c}0.81^{* * *} \\
(0.01)\end{array}$ & $\begin{array}{c}0.64^{* * *} \\
(0.00)\end{array}$ & $\begin{array}{c}0.62^{* * * *} \\
(0.00)\end{array}$ \\
\hline Difference & $\begin{array}{l}0.26^{* * *} \\
(0.00)\end{array}$ & $\begin{array}{l}0.07^{* * *} \\
(0.01)\end{array}$ & $\begin{array}{l}0.24^{* * *} \\
(0.00)\end{array}$ & $\begin{array}{l}0.27^{* * *} \\
(0.00)\end{array}$ \\
\hline Explained & $\begin{array}{l}-0.00^{* *} \\
(0.00)\end{array}$ & $\begin{array}{c}-0.01^{* * * *} \\
(0.00)\end{array}$ & $\begin{array}{c}0.01^{* * *} \\
(0.00)\end{array}$ & $\begin{array}{c}-0.00^{* * * *} \\
(0.00)\end{array}$ \\
\hline Unexplained & $\begin{array}{c}0.26^{* * *} \\
(0.00)\end{array}$ & $\begin{array}{c}0.08^{* * *} \\
(0.01)\end{array}$ & $\begin{array}{c}0.24^{* * *} \\
(0.00)\end{array}$ & $\begin{array}{c}0.27^{* * *} \\
(0.00)\end{array}$ \\
\hline \multicolumn{5}{|l|}{ Explained } \\
\hline Age 20-29 & $\begin{array}{c}0.00^{* * *} \\
(0.00)\end{array}$ & $\begin{array}{c}0.00^{* * *} \\
(0.00)\end{array}$ & $\begin{array}{c}0.06 \\
(0.10)\end{array}$ & $\begin{array}{c}0.00^{* * *} \\
(0.00)\end{array}$ \\
\hline Age 30-39 & $\begin{array}{l}-0.00^{* *} \\
(0.00)\end{array}$ & $\begin{array}{l}-0.00^{* * *} \\
(0.00)\end{array}$ & $\begin{array}{l}-0.01 \\
(0.02)\end{array}$ & $\begin{array}{l}-0.00^{* * *} \\
(0.00)\end{array}$ \\
\hline Age 40-49 & $\begin{array}{l}-0.00^{* *} \\
(0.00)\end{array}$ & $\begin{array}{c}0.00^{* * *} \\
(0.00)\end{array}$ & $\begin{array}{l}-0.00 \\
(0.00)\end{array}$ & $\begin{array}{c}-0.00^{* * * *} \\
(0.00)\end{array}$ \\
\hline Age 50-59 & $\begin{array}{l}-0.00^{* *} \\
(0.00)\end{array}$ & $\begin{array}{c}-0.00^{* * *} \\
(0.00)\end{array}$ & $\begin{array}{l}-0.01 \\
(0.02)\end{array}$ & $\begin{array}{c}-0.00^{* * * *} \\
(0.00)\end{array}$ \\
\hline Couple & $\begin{array}{l}-0.00^{* *} \\
(0.00)\end{array}$ & $\begin{array}{c}-0.00^{* * *} \\
(0.00)\end{array}$ & $\begin{array}{l}-0.15 \\
(0.26)\end{array}$ & $\begin{array}{c}-0.00^{* * * *} \\
(0.00)\end{array}$ \\
\hline Single & $\begin{array}{l}-0.00^{* *} \\
(0.00)\end{array}$ & $\begin{array}{c}-0.00^{* * * *} \\
(0.00)\end{array}$ & $\begin{array}{l}-0.16 \\
(0.27)\end{array}$ & $\begin{array}{c}-0.00^{* * * *} \\
(0.00)\end{array}$ \\
\hline Divorced & $\begin{array}{c}0.00^{* * *} \\
(0.00)\end{array}$ & $\begin{array}{c}-0.00^{* * * *} \\
(0.00)\end{array}$ & $\begin{array}{c}0.03 \\
(0.05)\end{array}$ & $\begin{array}{c}0.00^{* * *} \\
(0.00)\end{array}$ \\
\hline Widowed & $\begin{array}{c}0.00 \\
(0.00)\end{array}$ & $\begin{array}{c}0.00 \\
(0.00)\end{array}$ & $\begin{array}{l}-0.00 \\
(0.00)\end{array}$ & $\begin{array}{c}0.00 \\
(0.00)\end{array}$ \\
\hline Children & $\begin{array}{l}-0.00^{* *} \\
(0.00)\end{array}$ & $\begin{array}{l}0.01^{* * *} \\
(0.00)\end{array}$ & $\begin{array}{l}-0.10 \\
(0.18)\end{array}$ & $\begin{array}{c}-0.00^{* * * *} \\
(0.00)\end{array}$ \\
\hline County01 & $\begin{array}{l}-0.00^{* *} \\
(0.00)\end{array}$ & $\begin{array}{c}-0.00^{* * *} \\
(0.00)\end{array}$ & $\begin{array}{l}-0.04 \\
(0.07)\end{array}$ & $\begin{array}{c}-0.00^{* * * *} \\
(0.00)\end{array}$ \\
\hline County03 & $\begin{array}{c}0.00 \\
(0.00)\end{array}$ & $\begin{array}{l}-0.00 \\
(0.00)\end{array}$ & $\begin{array}{c}0.00 \\
(0.00)\end{array}$ & $\begin{array}{c}0.00 \\
(0.00)\end{array}$ \\
\hline County04 & $\begin{array}{c}0.00 \\
(0.00)\end{array}$ & $\begin{array}{l}0.00^{* *} \\
(0.00)\end{array}$ & $\begin{array}{c}0.00 \\
(0.00)\end{array}$ & $\begin{array}{c}0.00 \\
(0.00)\end{array}$ \\
\hline County05 & $\begin{array}{c}0.00 \\
(0.00)\end{array}$ & $\begin{array}{c}-0.00^{* * * *} \\
(0.00)\end{array}$ & $\begin{array}{l}-0.00 \\
(0.00)\end{array}$ & $\begin{array}{l}0.00^{* * *} \\
(0.00)\end{array}$ \\
\hline County06 & $\begin{array}{l}-0.00^{* *} \\
(0.00)\end{array}$ & $\begin{array}{c}0.00^{* * *} \\
(0.00)\end{array}$ & $\begin{array}{c}0.00 \\
(0.01)\end{array}$ & $\begin{array}{c}-0.00^{* * * *} \\
(0.00)\end{array}$ \\
\hline County07 & $\begin{array}{l}-0.00^{* *} \\
(0.00)\end{array}$ & $\begin{array}{c}0.00^{* * *} \\
(0.00)\end{array}$ & $\begin{array}{c}0.00 \\
(0.01)\end{array}$ & $\begin{array}{c}-0.00^{* * * *} \\
(0.00)\end{array}$ \\
\hline County08 & $\begin{array}{l}0.00^{* *} \\
(0.00)\end{array}$ & $\begin{array}{l}0.00^{* * *} \\
(0.00)\end{array}$ & $\begin{array}{c}0.00 \\
(0.00)\end{array}$ & $\begin{array}{c}0.00^{* * *} \\
(0.00)\end{array}$ \\
\hline County09 & $\begin{array}{l}-0.00^{*} \\
(0.00)\end{array}$ & $\begin{array}{l}-0.00^{* *} \\
(0.00)\end{array}$ & $\begin{array}{l}-0.00 \\
(0.00)\end{array}$ & $\begin{array}{l}-0.00^{* *} \\
(0.00)\end{array}$ \\
\hline County10 & $\begin{array}{l}-0.00^{*} \\
(0.00)\end{array}$ & $\begin{array}{l}-0.00 \\
(0.00)\end{array}$ & $\begin{array}{l}-0.00 \\
(0.00)\end{array}$ & $\begin{array}{l}-0.00^{*} \\
(0.00)\end{array}$ \\
\hline County12 & $\begin{array}{l}0.00^{* * *} \\
(0.00)\end{array}$ & $\begin{array}{c}-0.00^{* * * *} \\
(0.00)\end{array}$ & $\begin{array}{c}0.01 \\
(0.02)\end{array}$ & $\begin{array}{c}0.00^{* * *} \\
(0.00)\end{array}$ \\
\hline County13 & $\begin{array}{l}0.00^{* *} \\
(0.00)\end{array}$ & $\begin{array}{l}0.00^{* * *} \\
(0.00)\end{array}$ & $\begin{array}{c}0.01 \\
(0.01)\end{array}$ & $\begin{array}{l}0.00^{* * *} \\
(0.00)\end{array}$ \\
\hline County14 & $\begin{array}{c}0.00 \\
(0.00)\end{array}$ & $\begin{array}{l}-0.00 \\
(0.00)\end{array}$ & $\begin{array}{l}-0.00 \\
(0.00)\end{array}$ & $\begin{array}{c}0.00 \\
(0.00)\end{array}$ \\
\hline
\end{tabular}




\begin{tabular}{|c|c|c|c|c|}
\hline County17 & $\begin{array}{c}-0.00^{* *} \\
(0.00)\end{array}$ & $\begin{array}{c}-0.00^{* * *} \\
(0.00)\end{array}$ & $\begin{array}{c}-0.01 \\
(0.02)\end{array}$ & $\begin{array}{c}-0.00^{* * *} \\
(0.00)\end{array}$ \\
\hline \multirow[t]{2}{*}{ County18 } & -0.00 & 0.00 & 0.00 & -0.00 \\
\hline & $(0.00)$ & $(0.00)$ & $(0.00)$ & $(0.00)$ \\
\hline \multirow[t]{2}{*}{ County19 } & 0.00 & 0.00 & -0.00 & 0.00 \\
\hline & $(0.00)$ & $(0.00)$ & $(0.00)$ & $(0.00)$ \\
\hline \multirow[t]{2}{*}{ County20 } & $-0.00^{*}$ & -0.00 & -0.00 & $-0.00^{*}$ \\
\hline & $(0.00)$ & $(0.00)$ & $(0.00)$ & $(0.00)$ \\
\hline \multirow[t]{2}{*}{ County21 } & -0.00 & 0.00 & -0.00 & $-0.00^{*}$ \\
\hline & $(0.00)$ & $(0.00)$ & $(0.00)$ & $(0.00)$ \\
\hline \multirow[t]{2}{*}{ County22 } & $-0.00^{*}$ & $-0.00^{* *}$ & -0.00 & $-0.00^{* * *}$ \\
\hline & $(0.00)$ & $(0.00)$ & $(0.00)$ & $(0.00)$ \\
\hline \multirow[t]{2}{*}{ County23 } & $-0.00^{* *}$ & $-0.00^{* * *}$ & -0.00 & $-0.00^{* * *}$ \\
\hline & $(0.00)$ & $(0.00)$ & $(0.00)$ & $(0.00)$ \\
\hline \multirow[t]{2}{*}{ County24 } & $-0.00^{* *}$ & $-0.00^{* * *}$ & -0.00 & $-0.00^{* * *}$ \\
\hline & $(0.00)$ & $(0.00)$ & $(0.00)$ & $(0.00)$ \\
\hline \multirow[t]{2}{*}{ County25 } & $-0.00^{*}$ & $-0.00^{* * *}$ & -0.00 & $-0.00^{* * *}$ \\
\hline & $(0.00)$ & $(0.00)$ & $(0.00)$ & $(0.00)$ \\
\hline \multirow[t]{2}{*}{ Pre-sec. $<9$} & $0.00^{* * *}$ & $0.00^{* * *}$ & 0.18 & $0.00^{* * *}$ \\
\hline & $(0.00)$ & $(0.00)$ & $(0.31)$ & $(0.00)$ \\
\hline \multirow[t]{2}{*}{ Pre-sec. 9} & $-0.00^{* *}$ & $-0.00^{* * *}$ & 0.01 & $-0.00^{* * *}$ \\
\hline & $(0.00)$ & $(0.00)$ & $(0.01)$ & $(0.00)$ \\
\hline \multirow[t]{2}{*}{ Secondary $<3$} & $-0.00^{* *}$ & $-0.00^{* * *}$ & -0.03 & $-0.00^{* * *}$ \\
\hline & $(0.00)$ & $(0.00)$ & $(0.05)$ & $(0.00)$ \\
\hline \multirow[t]{2}{*}{ Secondary 3} & $0.00^{* * *}$ & $0.01^{* * *}$ & 0.04 & $0.00^{* * *}$ \\
\hline & $(0.00)$ & $(0.00)$ & $(0.07)$ & $(0.00)$ \\
\hline \multirow[t]{2}{*}{ Post-sec. $<3$} & -0.00 & $-0.00^{* * *}$ & -0.00 & $0.00^{* *}$ \\
\hline & $(0.00)$ & $(0.00)$ & $(0.00)$ & $(0.00)$ \\
\hline \multirow[t]{2}{*}{ Post-sec. $>=3$} & $-0.00^{*}$ & $-0.01^{* * *}$ & -0.00 & $0.00^{* * *}$ \\
\hline & $(0.00)$ & $(0.00)$ & $(0.01)$ & $(0.00)$ \\
\hline \multirow[t]{2}{*}{ Scientific } & $-0.00^{* *}$ & $-0.01^{* * *}$ & -0.01 & $0.00^{* * *}$ \\
\hline & $(0.00)$ & $(0.00)$ & $(0.01)$ & $(0.00)$ \\
\hline \multirow[t]{2}{*}{ General } & $0.00^{* * *}$ & $-0.00^{* * *}$ & 0.05 & $0.00^{* * *}$ \\
\hline & $(0.00)$ & $(0.00)$ & $(0.09)$ & $(0.00)$ \\
\hline Pedagogics & $0.00^{* *}$ & $0.00^{* * *}$ & 0.00 & $0.00^{* * *}$ \\
\hline & $(0.00)$ & $(0.00)$ & $(0.00)$ & $(0.00)$ \\
\hline Humanities & $0.00^{*}$ & 0.00 & 0.01 & -0.00 \\
\hline & $(0.00)$ & $(0.00)$ & $(0.02)$ & $(0.00)$ \\
\hline Social sciences & $-0.00^{* *}$ & $-0.00^{* * *}$ & -0.00 & $-0.00^{* * *}$ \\
\hline & $(0.00)$ & $(0.00)$ & $(0.01)$ & $(0.00)$ \\
\hline Natural sciences & $0.00^{* *}$ & $0.00^{* * *}$ & 0.01 & $0.00^{* * *}$ \\
\hline & $(0.00)$ & $(0.00)$ & $(0.01)$ & $(0.00)$ \\
\hline Technical & $0.00^{* * *}$ & $0.00^{* * *}$ & 0.11 & $0.00^{* * *}$ \\
\hline & $(0.00)$ & $(0.00)$ & $(0.18)$ & $(0.00)$ \\
\hline Agriculture & $0.00^{* * *}$ & $0.00^{* * *}$ & 0.01 & $0.00^{* * *}$ \\
\hline & $(0.00)$ & $(0.00)$ & $(0.02)$ & $(0.00)$ \\
\hline Health & $-0.00^{*}$ & $0.00^{*}$ & 0.00 & $-0.00^{* *}$ \\
\hline & $(0.00)$ & $(0.00)$ & $(0.00)$ & $(0.00)$ \\
\hline Services & $0.00^{* * *}$ & $0.00^{* * *}$ & 0.01 & $0.00^{* * *}$ \\
\hline & $(0.00)$ & $(0.00)$ & $(0.01)$ & $(0.00)$ \\
\hline Type unknown & $0.00^{* * *}$ & $0.00^{* * *}$ & 0.01 & $0.00^{* * *}$ \\
\hline & $(0.00)$ & $(0.00)$ & $(0.02)$ & $(0.00)$ \\
\hline Unexplained & & & & \\
\hline Age 20-29 & $-0.01^{* * *}$ & $-0.03^{* * *}$ & $-0.01^{* * *}$ & $-0.01^{* * *}$ \\
\hline & $(0.00)$ & $(0.00)$ & $(0.00)$ & $(0.00)$ \\
\hline Age 30-39 & $0.00^{* * *}$ & 0.00 & $0.00^{* * *}$ & $0.00^{* *}$ \\
\hline & $(0.00)$ & $(0.00)$ & $(0.00)$ & $(0.00)$ \\
\hline Age 40-49 & $0.01^{* * *}$ & $0.01^{* * *}$ & 0.00 & $0.01^{* * *}$ \\
\hline & $(0.00)$ & $(0.00)$ & $(0.00)$ & $(0.00)$ \\
\hline Age 50-59 & $0.01^{* * *}$ & $0.00^{* * *}$ & $0.01^{* * *}$ & $0.01^{* * *}$ \\
\hline
\end{tabular}




\begin{tabular}{|c|c|c|c|c|}
\hline & $(0.00)$ & $(0.00)$ & $(0.00)$ & $(0.00)$ \\
\hline \multirow[t]{2}{*}{ Couple } & $0.02^{* * *}$ & $0.04^{* * *}$ & $0.01^{*}$ & $0.02^{* * *}$ \\
\hline & $(0.00)$ & $(0.01)$ & $(0.01)$ & $(0.00)$ \\
\hline \multirow[t]{2}{*}{ Single } & $-0.01^{* * *}$ & 0.00 & $-0.01^{* * *}$ & $-0.01^{* * *}$ \\
\hline & $(0.00)$ & $(0.01)$ & $(0.00)$ & $(0.00)$ \\
\hline \multirow[t]{2}{*}{ Divorced } & $-0.00^{* * *}$ & $-0.00^{*}$ & $-0.00^{* *}$ & $-0.00^{* *}$ \\
\hline & $(0.00)$ & $(0.00)$ & $(0.00)$ & $(0.00)$ \\
\hline \multirow[t]{2}{*}{ Widowed } & $0.00^{* *}$ & -0.00 & $0.00^{*}$ & $0.00^{*}$ \\
\hline & $(0.00)$ & $(0.00)$ & $(0.00)$ & $(0.00)$ \\
\hline \multirow[t]{2}{*}{ Children } & $0.04^{* * *}$ & $-0.01^{*}$ & $0.03^{* * *}$ & $0.04^{* * *}$ \\
\hline & $(0.00)$ & $(0.00)$ & $(0.00)$ & $(0.00)$ \\
\hline \multirow[t]{2}{*}{ County01 } & $-0.01^{* * *}$ & 0.00 & $-0.02^{* * *}$ & $-0.01^{* * *}$ \\
\hline & $(0.00)$ & $(0.01)$ & $(0.00)$ & $(0.00)$ \\
\hline \multirow[t]{2}{*}{ County03 } & -0.00 & 0.00 & $-0.00^{*}$ & -0.00 \\
\hline & $(0.00)$ & $(0.00)$ & $(0.00)$ & $(0.00)$ \\
\hline \multirow[t]{2}{*}{ County04 } & $0.00^{* * *}$ & -0.00 & $0.00^{* * *}$ & $0.00^{* * *}$ \\
\hline & $(0.00)$ & $(0.00)$ & $(0.00)$ & $(0.00)$ \\
\hline \multirow[t]{2}{*}{ County05 } & $0.00^{* *}$ & 0.00 & 0.00 & $0.00^{*}$ \\
\hline & $(0.00)$ & $(0.00)$ & $(0.00)$ & $(0.00)$ \\
\hline \multirow[t]{2}{*}{ County06 } & $-0.00^{* * *}$ & -0.00 & $-0.00^{*}$ & $-0.00^{* * *}$ \\
\hline & $(0.00)$ & $(0.00)$ & $(0.00)$ & $(0.00)$ \\
\hline \multirow[t]{2}{*}{ County07 } & $0.00^{* * *}$ & -0.00 & $0.00^{*}$ & $0.00^{*}$ \\
\hline & $(0.00)$ & $(0.00)$ & $(0.00)$ & $(0.00)$ \\
\hline \multirow[t]{2}{*}{ County08 } & $-0.00^{* * *}$ & 0.00 & $-0.00^{* *}$ & $-0.00^{* * *}$ \\
\hline & $(0.00)$ & $(0.00)$ & $(0.00)$ & $(0.00)$ \\
\hline \multirow[t]{2}{*}{ County09 } & 0.00 & 0.00 & 0.00 & 0.00 \\
\hline & $(0.00)$ & $(0.00)$ & $(0.00)$ & $(0.00)$ \\
\hline \multirow[t]{2}{*}{ County10 } & $0.00^{* *}$ & 0.00 & $0.00^{*}$ & $0.00^{*}$ \\
\hline & $(0.00)$ & $(0.00)$ & $(0.00)$ & $(0.00)$ \\
\hline \multirow[t]{2}{*}{ County12 } & $-0.00^{*}$ & 0.00 & $0.00^{*}$ & $-0.00^{* * *}$ \\
\hline & $(0.00)$ & $(0.00)$ & $(0.00)$ & $(0.00)$ \\
\hline \multirow[t]{2}{*}{ County13 } & $-0.00^{* * *}$ & $0.00^{*}$ & -0.00 & $-0.00^{* * *}$ \\
\hline & $(0.00)$ & $(0.00)$ & $(0.00)$ & $(0.00)$ \\
\hline \multirow[t]{2}{*}{ County14 } & $-0.00^{* * *}$ & -0.00 & -0.00 & $-0.00^{* * *}$ \\
\hline & $(0.00)$ & $(0.00)$ & $(0.00)$ & $(0.00)$ \\
\hline County17 & $-0.00^{* * *}$ & -0.00 & -0.00 & $-0.00^{* * *}$ \\
\hline & $(0.00)$ & $(0.00)$ & $(0.00)$ & $(0.00)$ \\
\hline County18 & -0.00 & -0.00 & -0.00 & -0.00 \\
\hline & $(0.00)$ & $(0.00)$ & $(0.00)$ & $(0.00)$ \\
\hline County19 & $-0.00^{* * *}$ & $-0.00^{* *}$ & -0.00 & $-0.00^{* * *}$ \\
\hline & $(0.00)$ & $(0.00)$ & $(0.00)$ & $(0.00)$ \\
\hline County20 & $0.00^{* *}$ & -0.00 & $0.00^{*}$ & $0.00^{*}$ \\
\hline & $(0.00)$ & $(0.00)$ & $(0.00)$ & $(0.00)$ \\
\hline County21 & $0.00^{* * *}$ & -0.00 & 0.00 & $0.00^{* * *}$ \\
\hline & $(0.00)$ & $(0.00)$ & $(0.00)$ & $(0.00)$ \\
\hline County22 & $0.00^{* * *}$ & -0.00 & 0.00 & $0.00^{* * *}$ \\
\hline & $(0.00)$ & $(0.00)$ & $(0.00)$ & $(0.00)$ \\
\hline County23 & 0.00 & -0.00 & -0.00 & $0.00^{* * *}$ \\
\hline & $(0.00)$ & $(0.00)$ & $(0.00)$ & $(0.00)$ \\
\hline County24 & 0.00 & 0.00 & $-0.00^{*}$ & $0.00^{*}$ \\
\hline & $(0.00)$ & $(0.00)$ & $(0.00)$ & $(0.00)$ \\
\hline County25 & -0.00 & -0.00 & -0.00 & -0.00 \\
\hline & $(0.00)$ & $(0.00)$ & $(0.00)$ & $(0.00)$ \\
\hline Pre-sec. $<9$ & $-0.01^{* * *}$ & $-0.01^{* * *}$ & $-0.01^{* * *}$ & $-0.01^{* * *}$ \\
\hline & $(0.00)$ & $(0.00)$ & $(0.00)$ & $(0.00)$ \\
\hline Pre-sec. 9 & $-0.00^{* * *}$ & -0.00 & $-0.00^{* * *}$ & $-0.00^{* * *}$ \\
\hline & $(0.00)$ & $(0.00)$ & $(0.00)$ & $(0.00)$ \\
\hline Post-sec. $<3$ & $-0.01^{* * *}$ & -0.00 & $-0.01^{* * *}$ & $-0.01^{* * *}$ \\
\hline & $(0.00)$ & $(0.00)$ & $(0.00)$ & $(0.00)$ \\
\hline Secondary 3 & -0.00 & $0.00^{* *}$ & 0.00 & $-0.00^{* * *}$ \\
\hline
\end{tabular}




\begin{tabular}{|c|c|c|c|c|}
\hline & $(0.00)$ & $(0.00)$ & $(0.00)$ & $(0.00)$ \\
\hline \multirow{2}{*}{ Post-sec. $<3$} & $0.00^{* * *}$ & -0.00 & $0.01^{* * *}$ & $0.00^{* * *}$ \\
\hline & $(0.00)$ & $(0.00)$ & $(0.00)$ & $(0.00)$ \\
\hline \multirow[t]{2}{*}{ Post-sec. >=3 } & $0.01^{* * *}$ & $0.02^{* *}$ & $0.01^{* * *}$ & $0.01^{* * *}$ \\
\hline & $(0.00)$ & $(0.01)$ & $(0.00)$ & $(0.00)$ \\
\hline \multirow{2}{*}{ Scientific } & $0.00^{* * * *}$ & $0.01^{* * * *}$ & $0.00^{* * * *}$ & $0.00^{* * *}$ \\
\hline & $(0.00)$ & $(0.00)$ & $(0.00)$ & $(0.00)$ \\
\hline \multirow[t]{2}{*}{ General } & $0.00^{* * * *}$ & -0.00 & 0.00 & $0.01^{* * *}$ \\
\hline & $(0.00)$ & $(0.00)$ & $(0.00)$ & $(0.00)$ \\
\hline \multirow{2}{*}{ Pedagogics } & $0.00^{* * * *}$ & 0.00 & 0.00 & $0.00^{* *}$ \\
\hline & $(0.00)$ & $(0.00)$ & $(0.00)$ & $(0.00)$ \\
\hline \multirow[t]{2}{*}{ Humanities } & $-0.00^{* * * *}$ & $-0.00^{* *}$ & $-0.00^{* * * *}$ & -0.00 \\
\hline & $(0.00)$ & $(0.00)$ & $(0.00)$ & $(0.00)$ \\
\hline \multirow[t]{2}{*}{ Social sciences } & -0.00 & 0.00 & 0.00 & -0.00 \\
\hline & $(0.00)$ & $(0.00)$ & $(0.00)$ & $(0.00)$ \\
\hline \multirow[t]{2}{*}{ Natural sciences } & $-0.00^{* * *}$ & $-0.01^{* *}$ & $-0.00^{* * * *}$ & $-0.00^{* *}$ \\
\hline & $(0.00)$ & $(0.00)$ & $(0.00)$ & $(0.00)$ \\
\hline \multirow[t]{2}{*}{ Technical } & 0.00 & $-0.01^{* *}$ & 0.00 & $0.00^{* *}$ \\
\hline & $(0.00)$ & $(0.00)$ & $(0.00)$ & $(0.00)$ \\
\hline \multirow[t]{2}{*}{ Agriculture } & $0.00^{* * * *}$ & 0.00 & $0.00^{* *}$ & $0.00^{* * *}$ \\
\hline & $(0.00)$ & $(0.00)$ & $(0.00)$ & $(0.00)$ \\
\hline \multirow[t]{2}{*}{ Health } & $-0.00^{* * *}$ & 0.00 & $-0.00^{* * *}$ & $-0.00^{* * *}$ \\
\hline & $(0.00)$ & $(0.00)$ & $(0.00)$ & $(0.00)$ \\
\hline \multirow{2}{*}{ Services } & $0.00^{* * * *}$ & $0.00^{*}$ & $0.00^{*}$ & $0.00^{* *}$ \\
\hline & $(0.00)$ & $(0.00)$ & $(0.00)$ & $(0.00)$ \\
\hline \multirow[t]{2}{*}{ Type unknown } & $-0.00^{* * *}$ & 0.00 & 0.00 & $-0.00^{* *}$ \\
\hline & $(0.00)$ & $(0.00)$ & $(0.00)$ & $(0.00)$ \\
\hline \multirow[t]{2}{*}{ Constant } & $0.23^{* * *}$ & $0.07^{* *}$ & $0.23^{* * *}$ & $0.24^{* * * *}$ \\
\hline & $(0.01)$ & $(0.03)$ & $(0.01)$ & $(0.01)$ \\
\hline $\bar{v}$ & $1,816,109$ & $1,702,307$ & $1,728,253$ & $1,783,669$ \\
\hline
\end{tabular}

Table 11 Immigrant-native employment gap by source region: all men

\begin{tabular}{ccccccc}
\hline & All & $\begin{array}{c}\text { Rest of } \\
\text { Europe }\end{array}$ & Africa & $\begin{array}{c}\text { Asia w/o } \\
\text { Middle East }\end{array}$ & Middle East & $\begin{array}{c}\text { Rest of the } \\
\text { World }\end{array}$ \\
\hline Overall & & & & & & \\
Native & $0.88^{* * *}$ & $0.88^{* * *}$ & $0.88^{* * *}$ & $0.88^{* * *}$ & $0.88^{* * *}$ & $0.88^{* * *}$ \\
& $(0.00)$ & $(0.00)$ & $(0.00)$ & $(0.00)$ & $(0.00)$ & $(0.00)$ \\
Immigrant & $0.63^{* * *}$ & $0.74^{* * *}$ & $0.54^{* * *}$ & $0.65^{* * *}$ & $0.55^{* * *}$ & $0.71^{* * *}$ \\
& $(0.00)$ & $(0.00)$ & $(0.00)$ & $(0.00)$ & $(0.00)$ & $(0.01)$ \\
Difference & $0.26^{* * *}$ & $0.14^{* * *}$ & $0.34^{* * *}$ & $0.23^{* * *}$ & $0.34^{* * *}$ & $0.18^{* * *}$ \\
& $(0.00)$ & $(0.00)$ & $(0.00)$ & $(0.00)$ & $(0.00)$ & $(0.01)$ \\
Explained & $-0.00^{* *}$ & $-0.01^{* * *}$ & $0.01^{* * *}$ & $0.01^{* * *}$ & $-0.00^{* * *}$ & $-0.00^{* * *}$ \\
& $(0.00)$ & $(0.00)$ & $(0.00)$ & $(0.00)$ & $(0.00)$ & $(0.00)$ \\
Unexplained & $0.26^{* * *}$ & $0.15^{* * *}$ & $0.33^{* * *}$ & $0.22^{* * *}$ & $0.34^{* * *}$ & $0.18^{* * *}$ \\
& $(0.00)$ & $(0.00)$ & $(0.00)$ & $(0.00)$ & $(0.00)$ & $(0.01)$ \\
\hline Explained & & & & & & \\
Controls & $-0.01^{* *}$ & $-0.02^{* * *}$ & $-0.10^{* * *}$ & 0.07 & $-0.01^{* * *}$ & $-0.01^{* * *}$ \\
& $(0.00)$ & $(0.00)$ & $(0.01)$ & $(0.05)$ & $(0.00)$ & $(0.00)$ \\
Education & $0.00^{* * *}$ & $0.01^{* * *}$ & $0.07^{* * *}$ & -0.03 & $0.00^{* * *}$ & $-0.00^{* * *}$ \\
& $(0.00)$ & $(0.00)$ & $(0.01)$ & $(0.02)$ & $(0.00)$ & $(0.00)$ \\
Educ. type & $0.00^{* * * *}$ & $0.00^{* * * *}$ & $0.04^{* * *}$ & -0.04 & $0.00^{* * *}$ & $0.01^{* * *}$ \\
& $(0.00)$ & $(0.00)$ & $(0.01)$ & $(0.02)$ & $(0.00)$ & $(0.00)$ \\
\hline Unexplained & & & & & & \\
Controls & $0.03^{* * *}$ & $0.03^{* * *}$ & -0.01 & 0.01 & $0.04^{* * *}$ & -0.02 \\
& $(0.00)$ & $(0.01)$ & $(0.01)$ & $(0.01)$ & $(0.01)$ & $(0.02)$ \\
Education & $-0.00^{*}$ & $-0.01^{* * *}$ & -0.00 & $-0.00^{*}$ & 0.00 & $0.02^{* * *}$
\end{tabular}




\begin{tabular}{ccccccc} 
& $(0.00)$ & $(0.00)$ & $(0.00)$ & $(0.00)$ & $(0.00)$ & $(0.00)$ \\
Educ. Type & 0.00 & -0.00 & 0.00 & -0.00 & $0.01^{*}$ & -0.00 \\
Constant & $(0.00)$ & $(0.00)$ & $(0.00)$ & $(0.00)$ & $(0.00)$ & $(0.00)$ \\
& $0.23^{* * *}$ & $0.13^{* * *}$ & $0.34^{* * *}$ & $0.22^{* * *}$ & $0.29^{* * *}$ & $0.19^{* * *}$ \\
\hline$N$ & $(0.01)$ & $(0.01)$ & $(0.01)$ & $(0.02)$ & $(0.01)$ & $(0.02)$ \\
\hline
\end{tabular}

Notes: Robust standard errors in parentheses; ${ }^{*} p<0.05,{ }^{* *} p<0.01,{ }^{* * *} p<0.001$

Table 12 Immigrant-native employment gap by source region: male labor immigrants

\begin{tabular}{|c|c|c|c|c|c|c|}
\hline & All & $\begin{array}{l}\text { Rest of } \\
\text { Europe }\end{array}$ & Africa & $\begin{array}{c}\text { Asia w/o } \\
\text { Middle East }\end{array}$ & Middle East & $\begin{array}{c}\text { Rest of the } \\
\text { World }\end{array}$ \\
\hline \multicolumn{7}{|l|}{ Overall } \\
\hline Native & $\begin{array}{c}0.88^{* * *} \\
(0.00)\end{array}$ & $\begin{array}{c}0.88^{* * *} \\
(0.00)\end{array}$ & $\begin{array}{c}0.88^{* * *} \\
(0.00)\end{array}$ & $\begin{array}{c}0.88^{* * *} \\
(0.00)\end{array}$ & $\begin{array}{c}0.88^{* * *} \\
(0.00)\end{array}$ & $\begin{array}{c}0.88^{* * *} \\
(0.00)\end{array}$ \\
\hline Immigrant & $\begin{array}{c}0.81^{* * *} \\
(0.01)\end{array}$ & $\begin{array}{c}0.81^{* * *} \\
(0.02)\end{array}$ & $\begin{array}{l}0.78^{* * *} \\
(0.02)\end{array}$ & $\begin{array}{l}0.81^{* * *} \\
(0.01)\end{array}$ & $\begin{array}{l}0.83^{* * *} \\
(0.02)\end{array}$ & $\begin{array}{c}0.75^{* * *} \\
(0.02)\end{array}$ \\
\hline Difference & $\begin{array}{c}0.07^{* * *} \\
(0.01)\end{array}$ & $\begin{array}{c}0.07^{* * *} \\
(0.02)\end{array}$ & $\begin{array}{l}0.10^{* * * *} \\
(0.02)\end{array}$ & $\begin{array}{c}0.07^{* * *} \\
(0.01)\end{array}$ & $\begin{array}{l}0.05^{* *} \\
(0.02)\end{array}$ & $\begin{array}{c}0.13^{* * *} \\
(0.02)\end{array}$ \\
\hline Explained & $\begin{array}{c}-0.01^{* * *} \\
(0.00)\end{array}$ & $\begin{array}{c}-0.01^{* * * *} \\
(0.00)\end{array}$ & $\begin{array}{c}-0.03^{* * *} \\
(0.00)\end{array}$ & $\begin{array}{c}-0.02^{* * * *} \\
(0.00)\end{array}$ & $\begin{array}{l}0.01^{*} \\
(0.00)\end{array}$ & $\begin{array}{c}-0.02^{* * * *} \\
(0.00)\end{array}$ \\
\hline Unexplained & $\begin{array}{l}0.09^{* * *} \\
(0.01)\end{array}$ & $\begin{array}{l}0.08^{* * *} \\
(0.02)\end{array}$ & $\begin{array}{l}0.13^{* * *} \\
(0.02)\end{array}$ & $\begin{array}{c}0.09^{* * *} \\
(0.01)\end{array}$ & $\begin{array}{l}0.05^{*} \\
(0.02) \\
\end{array}$ & $\begin{array}{l}0.15^{* * *} \\
(0.02)\end{array}$ \\
\hline \multicolumn{7}{|l|}{ Explained } \\
\hline Controls & $\begin{array}{l}-0.00 \\
(0.00)\end{array}$ & $\begin{array}{c}-0.01^{* *} \\
(0.00)\end{array}$ & $\begin{array}{c}-0.01^{* * *} \\
(0.00)\end{array}$ & $\begin{array}{l}-0.00 \\
(0.00)\end{array}$ & $\begin{array}{l}0.01^{*} \\
(0.00)\end{array}$ & $\begin{array}{l}-0.01 \\
(0.00)\end{array}$ \\
\hline Education & $\begin{array}{c}-0.02^{* * *} \\
(0.00)\end{array}$ & $\begin{array}{c}-0.01^{* * * *} \\
(0.00)\end{array}$ & $\begin{array}{c}-0.02^{* * *} \\
(0.00)\end{array}$ & $\begin{array}{c}-0.02^{* * * *} \\
(0.00)\end{array}$ & $\begin{array}{l}-0.00 \\
(0.00)\end{array}$ & $\begin{array}{c}-0.02^{* * *} \\
(0.00)\end{array}$ \\
\hline Educ. type & $\begin{array}{l}0.01^{* * *} \\
(0.00)\end{array}$ & $\begin{array}{l}0.01^{* * *} \\
(0.00)\end{array}$ & $\begin{array}{l}0.01^{* * *} \\
(0.00)\end{array}$ & $\begin{array}{l}0.00^{* * *} \\
(0.00)\end{array}$ & $\begin{array}{l}0.00^{* * * *} \\
(0.00)\end{array}$ & $\begin{array}{l}0.01^{* * *} \\
(0.00)\end{array}$ \\
\hline \multicolumn{7}{|l|}{ Unexplained } \\
\hline Controls & $\begin{array}{c}0.02 \\
(0.03)\end{array}$ & $\begin{array}{c}0.04 \\
(0.03)\end{array}$ & $\begin{array}{l}-0.08 \\
(0.09)\end{array}$ & $\begin{array}{l}-0.01 \\
(0.06)\end{array}$ & $\begin{array}{l}-0.05 \\
(0.04)\end{array}$ & $\begin{array}{l}-0.03 \\
(0.05)\end{array}$ \\
\hline Education & $\begin{array}{c}0.02 \\
(0.01)\end{array}$ & $\begin{array}{l}-0.00 \\
(0.02)\end{array}$ & $\begin{array}{l}-0.05 \\
(0.09)\end{array}$ & $\begin{array}{c}0.07 \\
(0.04)\end{array}$ & $\begin{array}{c}0.00 \\
(0.02)\end{array}$ & $\begin{array}{l}-0.04 \\
(0.07)\end{array}$ \\
\hline Educ. type & $\begin{array}{c}-0.02^{* *} \\
(0.01)\end{array}$ & $\begin{array}{l}-0.02 \\
(0.01)\end{array}$ & $\begin{array}{l}-0.01 \\
(0.04)\end{array}$ & $\begin{array}{l}-0.04^{* *} \\
(0.01)\end{array}$ & $\begin{array}{l}-0.04 \\
(0.03)\end{array}$ & $\begin{array}{l}-0.04 \\
(0.03)\end{array}$ \\
\hline Constant & $\begin{array}{c}0.08^{*} \\
(0.03)\end{array}$ & $\begin{array}{c}0.07 \\
(0.04) \\
\end{array}$ & $\begin{array}{c}0.27^{*} \\
(0.12)\end{array}$ & $\begin{array}{c}0.08 \\
(0.07) \\
\end{array}$ & $\begin{array}{c}0.14^{*} \\
(0.06)\end{array}$ & $\begin{array}{l}0.25^{* *} \\
(0.09)\end{array}$ \\
\hline$N$ & $1,702,307$ & $1,424,651$ & $1,463,124$ & $1,573,605$ & $1,374,971$ & $1,425,677$ \\
\hline
\end{tabular}

Notes: Robust standard errors in parentheses; ${ }^{*} p<0.05,{ }^{* *} p<0.01,{ }^{* * *} p<0.001$

Table 13 Immigrant-native employment gap by source region: male family immigrants

\begin{tabular}{lllllll}
\hline & All & $\begin{array}{c}\text { Rest of } \\
\text { Europe }\end{array}$ & Africa & $\begin{array}{c}\text { Asia w/o } \\
\text { Middle East }\end{array}$ & Middle East & $\begin{array}{c}\text { Rest of the } \\
\text { World }\end{array}$ \\
\hline $\begin{array}{l}\text { Overall } \\
\text { Native }\end{array}$ & $0.88^{* * *}$ & $0.88^{* * *}$ & $0.88^{* * *}$ & $0.88^{* * *}$ & $0.88^{* * *}$ & $0.88^{* * *}$ \\
Immigrant & $(0.00)$ & $(0.00)$ & $(0.00)$ & $(0.00)$ & $(0.00)$ & $(0.00)$ \\
& $0.64^{* * *}$ & $0.71^{* * *}$ & $0.57^{* * *}$ & $0.66^{* * *}$ & $0.59^{* * *}$ & $0.69^{* * *}$ \\
Difference & $(0.00)$ & $(0.01)$ & $(0.01)$ & $(0.01)$ & $(0.01)$ & $(0.01)$ \\
& $0.24^{* * *}$ & $0.17^{* * *}$ & $0.31^{* * *}$ & $0.22^{* * *}$ & $0.30^{* * *}$ & $0.19^{* * *}$ \\
Explained & $(0.00)$ & $(0.01)$ & $(0.01)$ & $(0.01)$ & $(0.01)$ & $(0.01)$ \\
& $0.01^{* * *}$ & $-0.00^{*}$ & $0.01^{* * *}$ & $0.02^{* * *}$ & $0.02^{* * *}$ & $-0.01^{* * *}$ \\
Unexplained & $(0.00)$ & $(0.00)$ & $(0.00)$ & $(0.00)$ & $(0.00)$ & $(0.00)$ \\
& $0.24^{* * *}$ & $0.18^{* * *}$ & $0.30^{* * *}$ & $0.20^{* * *}$ & $0.28^{* * *}$ & $0.20^{* * *}$ \\
& $(0.00)$ & $(0.01)$ & $(0.01)$ & $(0.01)$ & $(0.01)$ & $(0.01)$
\end{tabular}




\begin{tabular}{|c|c|c|c|c|c|c|}
\hline \multicolumn{7}{|l|}{ Explained } \\
\hline Controls & $\begin{array}{l}-0.38 \\
(0.66)\end{array}$ & $\begin{array}{c}-0.01^{* * *} \\
(0.00)\end{array}$ & $\begin{array}{c}-0.07^{* * *} \\
(0.02)\end{array}$ & $\begin{array}{c}-0.02^{* * *} \\
(0.00)\end{array}$ & $\begin{array}{c}-0.05^{* * *} \\
(0.01)\end{array}$ & $\begin{array}{c}-0.01^{* * *} \\
(0.00)\end{array}$ \\
\hline Education & $\begin{array}{c}0.18 \\
(0.31)\end{array}$ & $\begin{array}{l}0.01^{* * *} \\
(0.00)\end{array}$ & $\begin{array}{c}0.04^{* * *} \\
(0.01)\end{array}$ & $\begin{array}{c}0.01^{* * *} \\
(0.00)\end{array}$ & $\begin{array}{l}0.04^{* * *} \\
(0.00)\end{array}$ & $\begin{array}{c}-0.00^{* * *} \\
(0.00)\end{array}$ \\
\hline Educ. type & $\begin{array}{c}0.21 \\
(0.35) \\
\end{array}$ & $\begin{array}{l}0.00^{* * * *} \\
(0.00)\end{array}$ & $\begin{array}{l}0.04^{* * *} \\
(0.01)\end{array}$ & $\begin{array}{l}0.02^{* * *} \\
(0.00)\end{array}$ & $\begin{array}{l}0.03^{* * *} \\
(0.00)\end{array}$ & $\begin{array}{l}0.01^{* * *} \\
(0.00)\end{array}$ \\
\hline \multicolumn{7}{|l|}{ Unexplained } \\
\hline Controls & $\begin{array}{c}0.00 \\
(0.01)\end{array}$ & $\begin{array}{c}0.01 \\
(0.02)\end{array}$ & $\begin{array}{l}-0.02 \\
(0.02)\end{array}$ & $\begin{array}{c}0.01 \\
(0.04)\end{array}$ & $\begin{array}{l}-0.00 \\
(0.02)\end{array}$ & $\begin{array}{l}-0.05^{*} \\
(0.03)\end{array}$ \\
\hline Education & $\begin{array}{l}-0.00 \\
(0.00)\end{array}$ & $\begin{array}{l}-0.01 \\
(0.01)\end{array}$ & $\begin{array}{l}-0.00 \\
(0.01)\end{array}$ & $\begin{array}{l}-0.00 \\
(0.00)\end{array}$ & $\begin{array}{l}-0.01 \\
(0.01)\end{array}$ & $\begin{array}{l}0.01^{*} \\
(0.01)\end{array}$ \\
\hline Educ. type & $\begin{array}{c}0.00 \\
(0.00)\end{array}$ & $\begin{array}{c}0.00 \\
(0.01)\end{array}$ & $\begin{array}{l}-0.01 \\
(0.01)\end{array}$ & $\begin{array}{l}-0.00 \\
(0.01)\end{array}$ & $\begin{array}{l}-0.00 \\
(0.01)\end{array}$ & $\begin{array}{l}-0.00 \\
(0.00)\end{array}$ \\
\hline Constant & $\begin{array}{l}0.23^{* * *} \\
(0.01)\end{array}$ & $\begin{array}{l}0.18^{* * * *} \\
(0.02)\end{array}$ & $\begin{array}{l}0.33^{* * *} \\
(0.02)\end{array}$ & $\begin{array}{l}0.19^{* * *} \\
(0.04)\end{array}$ & $\begin{array}{l}0.29^{* * *} \\
(0.03)\end{array}$ & $\begin{array}{l}0.24^{* * *} \\
(0.03)\end{array}$ \\
\hline$N$ & $1,728,253$ & $1,705,958$ & $1,705,201$ & $1,702,663$ & $1,706,904$ & $1,703,767$ \\
\hline
\end{tabular}

Notes: Robust standard errors in parentheses; ${ }^{*} p<0.05,{ }^{* *} p<0.01,{ }^{* * *} p<0.001$

Table 14 Immigrant-native employment gap by source region: male humanitarian immigrants

\begin{tabular}{|c|c|c|c|c|c|c|}
\hline & All & $\begin{array}{l}\text { Rest of } \\
\text { Europe }\end{array}$ & Africa & $\begin{array}{c}\text { Asia w/o } \\
\text { Middle East }\end{array}$ & Middle East & $\begin{array}{l}\text { Rest of the } \\
\text { World }\end{array}$ \\
\hline \multicolumn{7}{|l|}{ Overall } \\
\hline Native & $\begin{array}{l}0.88^{* * *} \\
(0.00)\end{array}$ & $\begin{array}{l}0.88^{* * *} \\
(0.00)\end{array}$ & $\begin{array}{l}0.88^{* * *} \\
(0.00)\end{array}$ & $\begin{array}{l}0.88^{* * *} \\
(0.00)\end{array}$ & $\begin{array}{l}0.88^{* * *} \\
(0.00)\end{array}$ & $\begin{array}{l}0.88^{* * *} \\
(0.00)\end{array}$ \\
\hline Immigrant & $\begin{array}{l}0.62^{* * *} \\
(0.00)\end{array}$ & $\begin{array}{l}0.74^{* * *} \\
(0.00)\end{array}$ & $\begin{array}{l}0.51^{* * *} \\
(0.01)\end{array}$ & $\begin{array}{l}0.61^{* * *} \\
(0.01)\end{array}$ & $\begin{array}{l}0.53^{* * *} \\
(0.00)\end{array}$ & $\begin{array}{l}0.73^{* * *} \\
(0.01)\end{array}$ \\
\hline Difference & $\begin{array}{l}0.27^{* * * *} \\
(0.00)\end{array}$ & $\begin{array}{l}0.14^{* * * *} \\
(0.00)\end{array}$ & $\begin{array}{l}0.37^{* * *} \\
(0.01)\end{array}$ & $\begin{array}{l}0.28^{* * *} \\
(0.01)\end{array}$ & $\begin{array}{l}0.35^{* * *} \\
(0.00)\end{array}$ & $\begin{array}{l}0.15^{* * *} \\
(0.01)\end{array}$ \\
\hline Explained & $\begin{array}{c}-0.00^{* * *} \\
(0.00)\end{array}$ & $\begin{array}{c}-0.01^{* * *} \\
(0.00)\end{array}$ & $\begin{array}{l}0.02^{* * *} \\
(0.00)\end{array}$ & $\begin{array}{l}0.00^{* *} \\
(0.00)\end{array}$ & $\begin{array}{c}-0.01^{* * *} \\
(0.00)\end{array}$ & $\begin{array}{l}0.00 \\
(0.00)\end{array}$ \\
\hline Unexplained & $\begin{array}{l}0.27^{* * *} \\
(0.00)\end{array}$ & $\begin{array}{l}0.15^{* * *} \\
(0.00)\end{array}$ & $\begin{array}{l}0.36^{* * * *} \\
(0.01)\end{array}$ & $\begin{array}{c}0.27^{* * *} \\
(0.01)\end{array}$ & $\begin{array}{l}0.35^{* * *} \\
(0.00)\end{array}$ & $\begin{array}{l}0.15^{* * *} \\
(0.01)\end{array}$ \\
\hline \multicolumn{7}{|l|}{ Explained } \\
\hline Controls & $\begin{array}{c}-0.01^{* * *} \\
(0.00)\end{array}$ & $\begin{array}{c}-0.02^{* * *} \\
(0.00)\end{array}$ & $\begin{array}{c}-0.11^{* * *} \\
(0.02)\end{array}$ & $\begin{array}{c}0.03 \\
(0.02)\end{array}$ & $\begin{array}{c}-0.02^{* * *} \\
(0.00)\end{array}$ & $\begin{array}{c}0.02 \\
(0.05)\end{array}$ \\
\hline Education & $\begin{array}{l}0.00^{* * *} \\
(0.00)\end{array}$ & $\begin{array}{l}0.01^{* * *} \\
(0.00)\end{array}$ & $\begin{array}{l}0.08^{* * * *} \\
(0.01)\end{array}$ & $\begin{array}{l}-0.02 \\
(0.01)\end{array}$ & $\begin{array}{l}0.01^{* * *} \\
(0.00)\end{array}$ & $\begin{array}{c}0.00 \\
(0.00)\end{array}$ \\
\hline Educ. type & $\begin{array}{l}0.00^{* * *} \\
(0.00)\end{array}$ & $\begin{array}{l}0.00^{* * * *} \\
(0.00)\end{array}$ & $\begin{array}{l}0.05^{* * *} \\
(0.01)\end{array}$ & $\begin{array}{l}-0.01 \\
(0.01)\end{array}$ & $\begin{array}{l}0.01^{* * *} \\
(0.00)\end{array}$ & $\begin{array}{l}-0.01 \\
(0.04)\end{array}$ \\
\hline \multicolumn{7}{|l|}{ Unexplained } \\
\hline Controls & $\begin{array}{l}0.04^{* * *} \\
(0.01)\end{array}$ & $\begin{array}{l}0.04^{* * *} \\
(0.01)\end{array}$ & $\begin{array}{c}0.00 \\
(0.01)\end{array}$ & $\begin{array}{c}0.03^{*} \\
(0.02)\end{array}$ & $\begin{array}{l}0.05^{* * *} \\
(0.01)\end{array}$ & $\begin{array}{l}-0.00 \\
(0.01)\end{array}$ \\
\hline Education & $\begin{array}{c}-0.01^{* * *} \\
(0.00)\end{array}$ & $\begin{array}{l}-0.01 \\
(0.00)\end{array}$ & $\begin{array}{l}-0.01 \\
(0.01)\end{array}$ & $\begin{array}{c}-0.02^{* * * *} \\
(0.01)\end{array}$ & $\begin{array}{l}-0.00 \\
(0.00)\end{array}$ & $\begin{array}{c}0.01 \\
(0.01)\end{array}$ \\
\hline Educ. type & $\begin{array}{c}0.00 \\
(0.00)\end{array}$ & $\begin{array}{l}-0.00 \\
(0.00)\end{array}$ & $\begin{array}{c}0.01 \\
(0.01)\end{array}$ & $\begin{array}{c}0.01 \\
(0.01)\end{array}$ & $\begin{array}{l}0.01^{* *} \\
(0.00)\end{array}$ & $\begin{array}{l}0.00 \\
(0.01)\end{array}$ \\
\hline Constant & $\begin{array}{l}0.24^{* * *} \\
(0.01)\end{array}$ & $\begin{array}{l}0.12^{* * * *} \\
(0.01)\end{array}$ & $\begin{array}{l}0.36^{* * *} \\
(0.02)\end{array}$ & $\begin{array}{l}0.25^{* * *} \\
(0.02)\end{array}$ & $\begin{array}{l}0.30^{* * * *} \\
(0.01)\end{array}$ & $\begin{array}{l}0.14^{* * *} \\
(0.02)\end{array}$ \\
\hline$N$ & $1,783,669$ & $1,729,042$ & $1,708,810$ & $1,693,600$ & $1,735,803$ & $1,684,963$ \\
\hline
\end{tabular}

